University of San Diego

Digital USD

Fall 10-12-2019

\title{
The Distribution and Demography of the Invasive Pacific Oyster, Crassostrea gigas, and Native Olympia Oyster, Ostrea lurida, in the San Diego River
}

Jason Langevin

University of San Diego

Follow this and additional works at: https://digital.sandiego.edu/theses

Part of the Biodiversity Commons, and the Population Biology Commons

\section{Digital USD Citation}

Langevin, Jason, "The Distribution and Demography of the Invasive Pacific Oyster, Crassostrea gigas, and Native Olympia Oyster, Ostrea lurida, in the San Diego River" (2019). Theses. 36.

https://digital.sandiego.edu/theses/36

This Thesis: Open Access is brought to you for free and open access by the Theses and Dissertations at Digital USD. It has been accepted for inclusion in Theses by an authorized administrator of Digital USD. For more information, please contact digital@sandiego.edu. 


\title{
UNIVERSITY OF SAN DIEGO
}

\author{
San Diego, California
}

The Distribution and Demography of the Invasive Pacific Oyster, Crassostrea gigas, and Native Olympia Oyster, Ostrea lurida, in the San Diego River

\begin{abstract}
A thesis submitted in partial satisfaction of the requirements for the degree of Master of Science in Environmental and Ocean Sciences

By Jason Langevin
\end{abstract}

Thesis Committee:

Jeff Crooks, Ph.D., Chair

Nathalie Reyns, Ph.D.

Drew Talley, Ph.D.

Theresa Talley, Ph.D. 
The thesis of Jason Langevin is approved by:

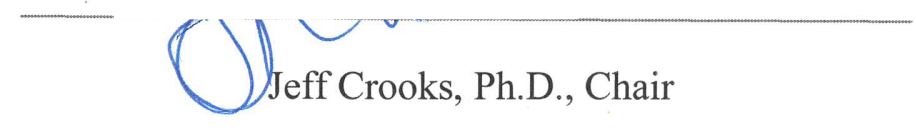

Drew Talley, Ph.D.

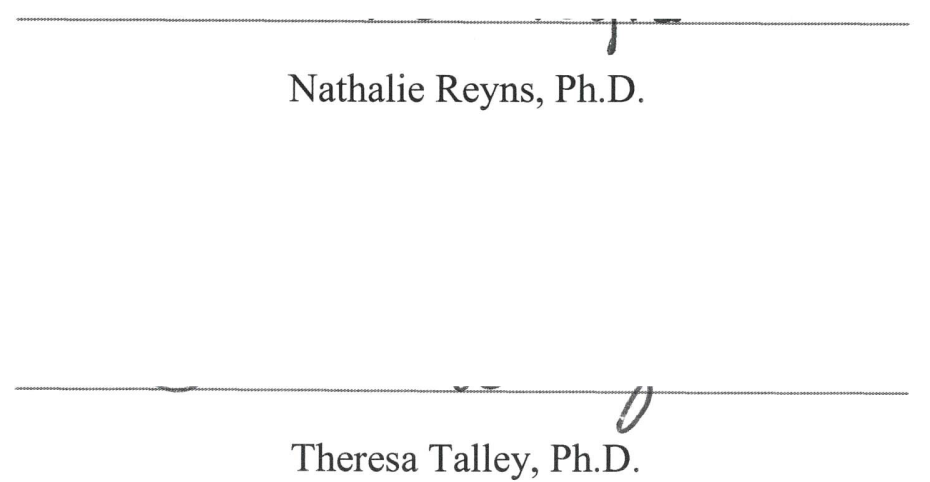


Copyright 2019 Jason Langevin 


\section{DEDICATION}

To my wife Christine and two daughters, Maya and Nina, who provided the encouragement and emotional support required for me to finish my research. 


\section{ACKNOWLEDGMENTS}

I would like to thank my thesis chair, Dr. Jeff Crooks, who spent countless hours in person, over the phone, and through emails working on this project with me, and I have been proud to have him as my mentor and friend. I would also like to thank the rest of my committee for their help with the project and suggestions for improving the research and paper, as well as their patience through the research. Special thanks go to my wife and daughters, who have provided the emotional

support required to get through the tough times of self-doubt. The University of San Diego provided the materials and supplies required to perform my research, as well as an additional grant for materials. I would also like to thank both Keith Fink and Eric Cathcart for their help using tools and knowledge during this project. 


\section{TABLE OF CONTENTS}

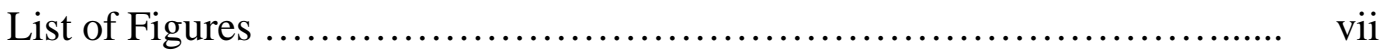

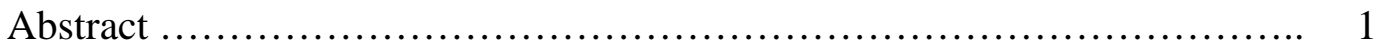

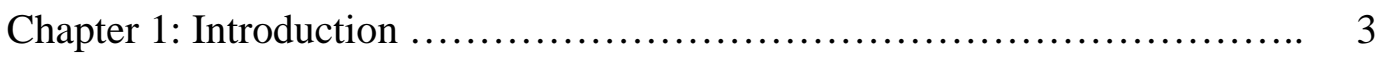

Chapter 2: Demography of Crassostrea gigas and Ostrea lurida ............ 5

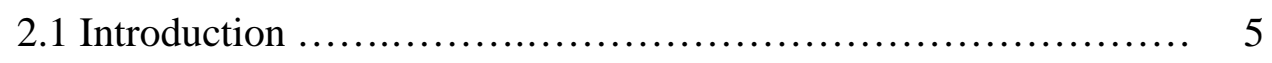

2.2 Methods ............................................................ 7

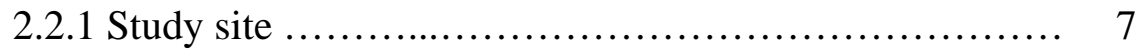

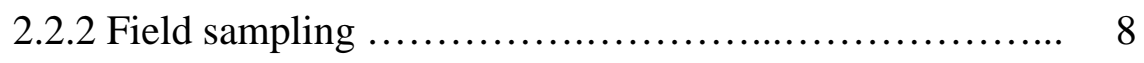

2.2.3 Laboratory processing $\ldots \ldots \ldots \ldots \ldots \ldots \ldots \ldots \ldots \ldots \ldots \ldots \ldots . . . . \ldots$

2.2.4 Data analysis .......................................... 9

2.3 Results .................................................. 11

2.3.1. Densities ................................................... 11

2.3.2 Biomass ................................................. 12

2.3.3 Condition Index ..................................... 13

2.3.4 Length-frequency distributions and growth rates ............ 13

2.3.5 Crassostrea gigas growth lines ............................. 14

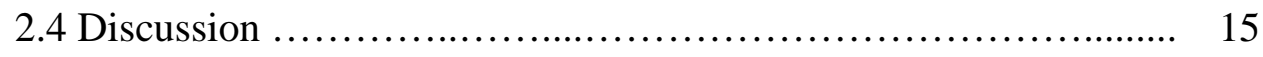

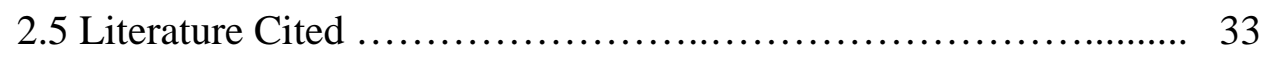

Chapter 3: Conclusions ............................................ 45

Appendix 1: Shell Morphology ..................................... 46

Appendix 2: Length-Weight Relationships ........................... 47 


\section{LIST OF FIGURES}

Figure 2.1. A) Map of study site (red dot) in the San Diego River. B) Photograph of transect along rip-rap bank of the San Diego River channel, facing upstream ...........................................

Figure 2.2 A) Detail of the chomata (grooves near umbo) found in Ostrea lurida. (B) Umbo of Crassostrea gigas, with the absence of chomata.

Figure 2.3. Cross section of Crassostrea gigas, displaying grey growth lines running through the interior of the shell.

Figure 2.4. Percentages of Ostrea lurida and Crassotrea gigas in the high-, mid- and low-intertidal zones in the San Diego River.

Figure 2.5. Mean densities of A) Ostrea lurida and B) Crassostrea gigas in the San Diego River.

Figure 2.6. Mean total biomass (shell weight plus dry tissue weight) of A) Ostrea lurida and B) Crassostrea gigas in the San Diego River.

Figure 2.7. Mean dry weights (tissue) of A) Ostrea lurida and B) Crassostrea gigas in the San Diego River.

Figure 2.8. Mean Condition Index (1000 x dry tissue weight / shell weight) for A) Ostrea lurida and B) Crassostrea gigas in the San Diego River.

Figure 2.9. Length-frequency distributions for Ostrea lurida and Crassostrea gigas in the San Diego River. $\mathrm{N}=$ total number of individuals.

Figure 2.10. Response Surface Analysis using ELEFAN to calculate growth rates $(\mathrm{K})$ and asymptotic size (Linf) of the Van Bertalanffy Growth Function for A) Ostrea lurida and (B) Crassostrea gigas.

Figure 2.11. Mean length vs. number of growth lines for Crassostrea gigas in the high-, mid-, and low-intertidal. 


\begin{abstract}
Even though the introduction of the Pacific Oyster, Crassostrea gigas, to the west coast of North America, happened roughly a century ago, it has only been in the past 15 to 20 years that $C$. gigas has started to become an established and conspicuous species along Southern California's coast. The establishment of C. gigas in Southern California has the potential to heavily influence many native species, as it has done globally. In Southern California, this invasion is particularly relevant for the native Olympia Oyster, Ostrea lurida. The Olympia oyster has both historical and present-day threats to its population, due to overfishing, pollution, and exotic species introductions. Understanding the distribution and demography of both species at the relatively early stage of $C$. gigas establishment is important for future management of both species.

In order to address this, sampling was conducted along the rip rap of the San Diego River, near its connection with the Pacific Ocean. Transects were laid down at the high, mid and low intertidal, and quadrats along these transects were sampled quarterly for one year. Densities, biomass, Condition Index, length frequencies, and Von Bertalanffy growth constants were used to look at the growth of the two species over this time period. For $C$. gigas, growth lines were also used as a tool to estimate age and growth. This work demonstrated that $O$. lurida densities were in fact much greater than those of $C$. gigas, but that these native oysters had greater numbers in the low intertidal and diminished as tidal height increased. Crassostrea gigas numbers also decreased with increase tidal height, although less dramatically than O. lurida. Even though there is a large size
\end{abstract}


difference between the two species, growth rate constants found using the Von Bertanlaffy growth model $(\mathrm{k})$ in the low- and mid-intertidal combined were found to be very similar, indicating similar growth rates. Further analysis of growth rates of $C$. gigas across tidal zones, using growth lines, demonstrated that the growth rate decreased as tidal elevation increased.

This study on the demography on native and invasive oysters in San Diego provides a foundation of baseline scientific information against which future change can be assessed, and can also inform future research directions, such as investigations of how each species interacts independently with their environment and with one another. 


\section{CHAPTER 1: INTRODUCTION}

The invasion of non-native species represents a fundamental way in which humans alter the integrity of marine ecosystems. In San Diego County’s marine waters alone, it is estimated that there are well over 100 established non-native species (Crooks et al. 2016). Among the most conspicuous of these is the Pacific oyster, Crassostrea gigas, which is native to Asia. This invasion appears to have occurred within the last 20 years, and has the potential to impact coastal ecosystems (Crooks et al., 2015). One species, the Pacific oyster likely will influence the smaller, native Olympia oyster, Ostrea lurida. Recent work in San Diego Bay, the largest embayment in Southern California, has indicated zonation of the two oyster species, with C. gigas being found at higher elevations than the native (Tronske et al. 2016).

This study examines demographic characteristics of both C. gigas and $O$. lurida across tidal zones in the San Diego River estuary. This system is characteristic of many estuaries in the region, as tidal influence is muted by an intertidal sill at the mouth. Over the course of one year, the density, biomass, size and growth of the two oyster species were tracked (Chapter 1). Additional information on shell morphology (Appendix 1) and lengh / weight relationships were also gathered (Appendix 2). This provides a foundation of basic scientific information, and can also inform future research directions for these two species (Chapter 3). 


\section{Literature Cited}

Crooks, J.A., Crooks, K.R., and Crooks, A.J. (2015). “Observations of the nonnative Pacific oyster (Crassostrea gigas) in San Diego County, California”. California Fish and Game 101:101-107.

Crooks, J.A., Talley, D.M. , Cordrey, M., Whitcraft, C., Lorda-Solorzano, J., Uyeda, K., Bellringer, H., McCullough, J., and Almeida, M. (2016). Unnatural history: Biological invasions into coastal ecosystems. Pages 193-203 in Proceedings of the US - Iran Symposium on Wetlands, March 28-30, 2016, Irvine, California.

Tronske, N. B., Parker, T. A., Henderson, H. D., Burnaford, J. L., \& Zacherl, D. C. (2018). "Densities and zonation patterns of native and non-Indigenous oysters in Southern California Bays.” Wetlands. 38(6): 1313-1326. 


\section{CHAPTER 2: DEMOGRAPHY OF CRASSOSTREA GIGAS AND OSTREA LURIDA}

\subsection{Introduction}

Oysters represent some of the most ecologically and economically important marine invertebrates. They modify habitats by providing protective structure, increase settling substrate for sessile organisms, filter water, and provide coastal barriers and “living shorelines” (Crooks and Turner 1990; Newell and Koch 2004; Swann 2008; Padilla 2010; Troost 2010). Along the Pacific coast of the United States and Canada, there is only one native oyster species, the Olympia oyster, Ostrea lurida. Individuals have been recorded living from Sitka, Alaska, down to Cabo San Lucas, Baja California Sur, Mexico (Carson 2010; Polson and Zacherl 2009). Ostrea lurida has been found in shell middens in San Diego dating back thousands of years (Baker 1995; Carson 2010). However, a fishery for $O$. lurida developed in the 19th century along the west coast of the United States but collapsed due to heavy overfishing (Polson and Zacherl 2009; Trimble et al. 2009). Thus, there is currently a focus on major restoration efforts of O. lurida along the west coast (Brumbaugh and Coen 2009; Groth and Rumrill 2009; Polson et al. 2009, M. Almeida et al. 1998.).

Due to dwindling O. lurida populations and a desire for new, larger species for the commercial market, the Japanese oyster, Crassostrea gigas, also known as the Pacific or Miyagi oyster, was introduced to the west coast of the United States (Carlton 1979). Native to Japan and Southeast Asia, C. gigas is currently established in at least seventeen countries and has been introduced in 
over sixty-five (Ruesink et al. 2005, Harris 2008). The first shipments of Japanese oysters into North America began in the early 1900's, with occasional introductions into Southern California from the 1930's to the 1980's (Carlton 1979, Crooks et al. 2015). There was no indication that C. gigas had established itself in San Diego California in the 20th century. However, in the early 2000's, reports of $C$. gigas in San Diego region began, possibly related to an aquaculture operation that began in northern San Diego County developed in the late 1990's (Crooks et al. 2015). Currently, C. gigas has been observed throughout San Diego County, including the Tijuana River Estuary, San Diego Bay, Mission Bay, Oceanside Harbor, Los Penasquitos Lagoon, and the San Diego River (Crooks et al. 2015; Merkel and Associates Inc, 2015; Tronske 2018). Many of these locations are also habitats for the native O. lurida (Carson 2010), and it has been reported that differences in tidal zonation between the two species are common, with O. lurida to inhabiting a lower tidal elevation than C. gigas (Merkel and Associates Inc, 2015, Tronske 2018).

Both species have been well-studied along the northwest coast of North America, where C. gigas considered to be "naturalized", but spread of $C$. gigas in Southern California is relatively recent and thus our understanding of this species' population dynamics and ecosystem effects in the region are only beginning to be realized (Crooks et al. 2015; Tronske et al.2018). In other regions, C. gigas outcompetes native bivalve species for space and food (Troost 2008, 2010), and this could present a problem for San Diego's much smaller native oyster $(O$. lurida) when both species are present. The main goal of this research is to 
improve our understanding of the basic population biology and potential community interactions of $C$. gigas at the mouth of an urban river during its early spread throughout Southern California. This goal was met by addressing two objectives: (1) documenting the distribution and demography of both species in Southern California, and (2) identifying tidal differences between the two species' distributions in the San Diego River, as reported elsewhere (Tronske et al. 2018). By understanding the tidal distribution and demography of both species' in a semi-arid, urbanized river in San Diego, comparisons can be made to other regions of the world, and a foundation can be established for future assessments of potential interactions between the two species.

\subsection{METHODS}

\subsubsection{Study site}

The San Diego River originates in the Cuyamaca Mountains and flows west, draining into the Pacific Ocean in San Diego, California. Once connected to both Mission Bay and the San Diego Bay, the San Diego River is now isolated from both systems (Canada 2006). The first major alteration to the lower San Diego River occurred in the mid-1800's when “Derby’s Dike” was created, as an attempt to prevent unwanted sediment from entering the port at San Diego Bay by diverting the river into Mission Bay (Pryde 2002). This initial dike failed, but additional construction resulted in a redirected San Diego River by 1876 (Papageorge 1971). The next major alteration came with the completion of the San Diego River flood control channel in 1953 (Papageorge 1971). The rip-rap 
levees and jetties now force the San Diego River to bypass both San Diego Bay and Mission Bay and instead flow directly into the ocean (Fig. 2.1A and 2.1B).

\subsubsection{Field sampling}

A 50-meter distance along the San Diego River was chosen to examine the demography of O. lurida and C. gigas, where both species are commonly found. During the first sampling season, October 2016, two tidal zones were examined, one representing the highest zone where oysters were observed and the other in the mid-intertidal (approximately 0.95 and 1.16 m NAVD88). During subsequent samplings, which occurred three months starting on October $19^{\text {th }}$, 2016, followed by samplings on January $9^{\text {th }}, 2017$, April 22 $2^{\text {nd }}, 2017$, July $24^{\text {th }}, 2017$ and September $20^{\text {th }}$. In January 2017 an additional zone in the low-intertidal, at approximately $0.68 \mathrm{~m}$ NAVD88, was added to the sampling design due to the observations of large numbers of oysters in the low intertidal zone. Elevation of the zones was determined by using RTK GPS (although some variability existed within each transect due to the large, three-dimensional nature of the rip rap surface).

At the 50-m long sampling site, the high-, mid- and low-tidal zones were divided into five $10-\mathrm{m}$ long transects. In each of these $10-\mathrm{m}$ transects, $0.5 \times 0.5 \mathrm{~m}$ quadrats were randomly selected for oyster assessments. Each quadrat was randomly assigned a number, 0-4, which represented the time sampling would occur. At each sampling, all oysters in the designated quadrat were removed by hand or with use of a chisel and hammer. Oysters were placed in plastic bags, 
brought back to the University of San Diego, and frozen for at least 48hrs at $80^{\circ} \mathrm{C}$.

\subsubsection{Laboratory processing}

In the laboratory, oysters were processed to assess shell characteristics, determine species identity, remove tissue for biomass assessments, and prepare $C$. gigas shells for growth ring analysis. Before dissection, oysters were removed from the freezer and placed in a refrigerator to allow easy shell access. Thawed oysters were then cleaned using a small scrub brush to remove any mud and organisms (other than oysters) growing on the shell. Total weight was measured to the nearest tenth of a gram. Length was measured from the hinge to the most distant point on the shell. After shell measurements, each individual oyster was opened, and the soft tissue was removed and placed into a glass beaker and wet weight of the soft tissue was taken. The soft tissue was then placed in an oven at $65^{\circ} \mathrm{C}$ for 48 hours to obtain dry tissue weights. Shell weight was measured for each individual oyster after drying for 24 hours. Species identifications were made by both examining the size of the individual (C. gigas attains much larger sizes than $O$. lurida), as well as examining shells for the presence of chomata near the hinge, which is only present in O. lurida (Fig. 2.2).

\subsubsection{Data analyses}

Abundance, oyster length, and biomass data were used to assess demography across species and tidal zones. Paired t-tests across dates were used 
to examine differences in density and biomass across time, and following recent American Statistical Association guidance, P-values are reported but no assessments of significance are made based on fixed alphas (Wasserstein et al. 2019). Length-frequency distributions were created for low- and mid-intertidal sites combined, this was done to increase sample sizes. The high intertidal was not included in the length frequency distribution because of small sampling sizes. Condition Indices, representing the ratio of dry flesh weight (x 1000) to shell weight (Mann and Glomb 1978) were also calculated for combined low- and midintertidal samples.

For both species oyster growth was determined by calculating the growth rate constant, K, in the Von Bertalanffy Growth Function (VBGF), using TropFishR. This R package is based on ELEFAN (ELectronic LEngth Frequency Analysis), (Pauly 1987, Schwamborn et. al, 2019), and calculates parameters of the VBGF, including $\mathrm{K}$ (the rate at which a species approaches average asymptotic size, Linf). The “Optimise” Response Surface Analysis method of ELEFAN was used, which provides best fits of both $\mathrm{K}$ and Linf.

Growth of C. gigas was also assessed using growth lines. Growth lines found in cross sections of bivalves have been used to estimate the age of oysters, including C. gigas (Harding and Mann 2006). Ostrea lurida was not known to have growth lines, and this is confirmed in preliminary worth for this study. After species identification, a total of 236 C. gigas oysters were selected for growth line counts, spanning the size range between the smallest and largest individuals. Cross sections were performed using a diamond table saw at the 
University of San Diego (Fig. 2.3). According to the criteria of Harding and Mann (2006), to be considered for growth ring analysis, a straight line from the end of the shell to the umbo should pass through the adductor scar. However, in this study, there were only 19 oysters that met this requirement. Therefore, all 236 selected oysters were considered for this work. Once cut, shells were dried, and lines were counted using a compound microscope. Following the methods of Harding and Mann (2006), growth lines were categorized as thick grey lines originating at the umbo continuing through the cross section to an ending point at the outer edge of the shell (Fig. 2.3).

Growth rates in each tidal zone were calculated as the slope of the line of size vs. age (inferred as the number of lines). This was conducted for oysters with up to three growth lines (the maximum number in the high-intertidal), and all oysters within quadrats and across times were pooled (i.e., treated as independent observations) to statistically compare slopes across tide zones.

\subsection{RESULTS}

\subsubsection{Densities}

Ostrea lurida was the more prevalent oyster species in two of the three sampled tidal heights but decreased more dramatically in abundance with increasing elevation than C. gigas. Out of all 512 oysters sampled in the lowintertidal, 75\% were O. lurida and 25\% were C. gigas (Fig. 2.4). Densities of $O$. lurida were approximately twice that of $C$. gigas in the low-intertidal, although there was relatively high variability within plots (paired t-test: $\mathrm{t}_{3}=2.33, \mathrm{P}=0.10$ ) 
(Fig. 2.5). As tidal height increased from the low- to mid-intertidal, the average density (across time) of $O$. lurida decreased $83 \%$ (paired t-test: $\mathrm{t}_{3}=8.97, \mathrm{P}=0.003$ ). The decrease of $C$. gigas from the low- to mid-intertidal was less pronounced (paired t-test: $\mathrm{t}_{3}=1.82, \mathrm{P}=0.17$ ), and during one sampling season (April 2017), mid-intertidal densities exceeded those in the low-intertidal. The densities of the two species were more comparable in the mid-intertidal (Figs. 2.4 and 2.5) (paired t-test: $\mathrm{t}_{4}=0.57, \mathrm{P}=0.60$ ). In the high-intertidal zone, few $C$. gigas were found and O. lurida were completely absent (Figs. 2.4 and 2.5).

\subsubsection{Biomass}

Differences in biomass, both in terms of dry flesh weight and total (dry flesh + shell) weight tended to be much more pronounced than differences in densities, driven by the larger sizes of $C$. gigas. The largest $C$. gigas collected was $227 \mathrm{~mm}$, while the largest $O$. lurida was $80 \mathrm{~mm}$. The average total weight of $C$. gigas per quadrat was 14 times larger than $O$. lurida in the low-intertidal (paired t-test: $\mathrm{t}_{3}=5.88, \mathrm{P}=0.01$ ), and 40 times larger in the mid-intertidal (paired t-test: $\mathrm{t}_{4}=3.05, \mathrm{P}=0.04$ ) (Fig. 2.6). Dry tissue biomass of $C$. gigas in the low-intertidal was 15 times larger than $O$. lurida in the same zone (paired t-test: $\mathrm{t}_{3}=7.38$, $\mathrm{P}=0.005$ ) (Fig. 2.7). In the mid-intertidal, the average difference was a factor of 30, but there was considerable variability, driven by very high biomass in April 2017 (paired t-test: $\mathrm{t}_{4}=1.68, \mathrm{P}=0.17$ ) (Fig. 2.7). With $O$. lurida being absent from the high inertial and so few C. gigas, a paired t-test was not performed between the species for either total or dry weight biomass in the high-intertidal zone. For 
both species, dry and total biomass weight tended to increase leading up to the spring, followed by a decrease during the summer and fall, with the one exception being C. gigas in the low-intertidal (Figs. 2.6 and 2.7).

\subsubsection{Condition Index}

Despite large differences in size and biomass, condition indices (representing the ratio of flesh weight (x 1000) to shell weight) for the two species tended to be comparable for the low- and mid-intertidal sites, ranging from 23 to 60 (Fig. 2.8). Also, there appeared to be some temporal differences in condition for C. gigas in the low- and mid-intertidal and O. lurida in the low-intertidal. In both cases, condition indices peaked in April 2017. Condition indices were much more variable for $O$. lurida in the mid-intertidal, although the species was less common there in the early seasons and absent from the last two sampling dates.

\subsubsection{Length-frequency distributions and growth rates}

The length-frequency histograms for combined low and mid-intertidal sites suggest some size structure in the populations and the appearance of distinct cohorts of different sizes. These are represented by peaks in the histograms (Fig. 2.9). The size of the smallest individuals found was similar for both species, with

C. gigas at $7 \mathrm{~mm}$ and $O$. lurida at $6 \mathrm{~mm}$. For C. gigas, individuals in the smallest size were found throughout the year (Fig. 2.9), suggesting the possibility of some continued recruitment. Ostrea lurida, on the other hand, had relatively few individuals in the smaller size class (Fig. 2.9). 
Length-frequency distributions for the two species were analyzed using the ELEFAN (ELectronic LEngth Frequency ANalysis) function of TropFishR to estimate two parameters of the Von Bertalanffy Growth Function (VBGF): the growth rate constant, $\mathrm{K}$, and asymptotic size. The Response Surface Analyses (Fig. 2.10 A and B) provided comparable growth rate estimates for the two species, with O. lurida having a value of $0.66 \mathrm{yr}^{-1}$ and C. gigas, $0.67 \mathrm{yr}^{-1}$ (Fig. 2.10 A and B). There was a large distinction between asymptotic sizes (which should be interpreted differently than absolute maximum size, which is the max size of sampled organisms; Mildenberger et al. 2019), with O. lurida at $47 \mathrm{~mm}$ and C. gigas $144 \mathrm{~mm}$ (Fig. 2.10 A and B).

\subsubsection{Crassostrea gigas growth lines}

Growth lines in C. gigas were apparent, with a maximum number of 8 lines recorded in the low-intertidal sites, 7 in the mid-intertidal, but only 3 in the high-intertidal. Assuming that lines are laid down annually, as has been determined for other species elsewhere (Richardson et al. 1993a; 1993b; Kirby et al. 1998;), this suggests that $C$. gigas in the high-intertidal did not live longer than three years, while those in lower tidal zones had maximum lifespans of more than twice as long. Oyster size as a function of age, inferred as the number of lines

(Fig. 2.11), also suggest differences in growth across zones, especially for young oysters. The rate of increase of size from 1-yr olds to 3-yr olds, compared as slopes of lines of size vs. age, decreased from the low to high-intertidal $\left(F_{2,159}=\right.$ $6.67, \mathrm{P}=0.0017)$ In the high-intertidal zone, the rate of increase was $17.5 \pm 3.2$ 
$\mathrm{mm} / \mathrm{yr}(\mathrm{N}=17)$, which was lower than the growth rate in the mid-intertidal of $28.4 \pm 7.4 \mathrm{~mm} / \mathrm{yr}(\mathrm{N}=76)$. Oysters in the low-intertidal had the highest early growth rate, $40.5 \pm 3.165 \mathrm{~mm} / \mathrm{yr}(\mathrm{N}=72)$.

\subsection{Discussion}

Two oyster species, the native Ostrea lurida and invasive Crassostrea gigas, are the most conspicuous invertebrates on the rock banks of the San Diego River. The density of these oyster species in the mid- and low-intertidal in this area (Fig. 2.5) resemble those of other populations found in Southern California (Newport Bay, Alamitos Bay, Huntington Harbour, Los Angeles Harbor, Mission Bay and San Diego Bay) (Polson and Zacherl 2009; Tronske 2009). However, compared to other locations along the west coast of the United States, densities were lower for both species. For example, O. lurida densities in San Francisco Bay ranged from 140 oysters $/ \mathrm{m}^{2}$ to 960 oysters $/ \mathrm{m}^{2}$ (Polson and Zacherl 2009; Wasson et al. 2015), while in Puget Sound C. gigas were found at 352 oysters $/ \mathrm{m}^{2}$ (Valdez et al. 2016). Globally density is variable depending on location. In Scandinavia, densities in Sweden ranged between 0.64 oysters $/ \mathrm{m}^{2}$ to 505 oysters $/ \mathrm{m}^{2}$, while in Denmark densities only reached 1.43 oysters $/ \mathrm{m}^{2}$ to 15.30 oysters/m² (Wrange et al. 2009). In Australia, densities ranged between less than 4 oysters/ $\mathrm{m}^{2}$ to 300 oysters $/ \mathrm{m}^{2}$, depending on substrate (Krassoi et al. 2008; Bishop et al. 2010). When first introduced in an area, C. gigas settlement often occurs on the shells of dead native bivalve species, such as mussel beds and other oyster species (Wehrmann et al. 2000; Diederich et al. 2004; Troost 2010). In 
many cases, these reefs develop into $C$. gigas / mussel reefs, with the mussels and oysters living together (Troost 2010).

A clear pattern of zonation between C. gigas and O. lurida was present in the San Diego River, as has been observed in other local embayment's. Crassostrea gigas favors the higher intertidal zone, while O. lurida the lower (Merkel and Associates Inc, 2015. Tronske et al. 2018). Crassostrea gigas in the San Diego River displayed comparable zonation patterns to that found in Puget Sound (Valdez et al. 2016), where five tidal elevations were examined and $C$. gigas densities increased with tidal elevation. Little is known about the cause of zonation between C. gigas and O. lurida. For O. lurida in Washington state (Puget Sound), higher recruitment has been documented at lower tidal elevations (Baker 1995, White et al. 2009a). Krassoi et al. (2008) suggest that competitive dominance and difference in abiotic factors (desiccation) could be a strong influence. Due to their larger size, C. gigas could be less prone to desiccation than O. lurida in the San Diego River at higher tide levels as seen with other bivalve species (Krassoi et al. 2008).

Crassostrea gigas is considered one of the largest living oyster species, with maximum sizes reported greater than 400 mm (Torigoe 1981). Although C. gigas in the San Diego River did not reach this size, they were still relatively large, with $227 \mathrm{~mm}$ as the maximum length. The largest $O$. lurida individual was $80 \mathrm{~mm}$, which was closer to the maximum size reported for the species of, 80-100 mm (Arakawa 1990; Peter-Contesse and Peabody 2005; Pritchard 2015). Because of the greater lengths of $C$. gigas compared to O. lurida, the overall (dry and total) 
biomass per quadrat of $C$. gigas was roughly 15 to 40 times larger than $O$. lurida, even though O. lurida densities tended to be higher than that of C. gigas in the low-intertidal. From a global perspective, the large, calcium-rich shells of oysters (like those created by C. gigas) act as potentially large organic carbon pools. For the reef-building C. virginica one dense reef has the potential to store over 400 million Mg carbon over a course of 300 years (Fodrie et al. 2017).

Analysis of length-frequency data throughout the sampling period provides some indication of timing of recruitment of both species. Crassostrea gigas had a peak in recruitment in April 2017 (Fig. 2.9). This coincided with the highest Condition Indices for the species (Figure 2.10), indicating increases in soft tissue biomass relative to shell size, possibly due to an increase in reproductive tissue. There was also constant recruitment occurring throughout the year for C. gigas, with individuals in the smallest size class collected during every time period. In other parts of the world, Crassostrea gigas have been shown to have variable reproductive periods. For example, on the South Island of New Zealand, individuals reproduce only once in the early spring, while on the North Island they have two or more spawns within a year (Dinamani 1987). Compared to C.gigas, O. lurida did not display a major recruitment period during the study although small individuals were found from October 2016 to April 2017. The cause of this low recruitment for $O$. lurida remains unknown.

Changing length-frequency distributions were also used to calculate and compare growth rates of $C$. gigas and $O$. lurida, expressed as a constant in the Von Bertalanffy Growth Function. Despite being different in size, the two species 
had similar K constants, indicating comparable rates at which the species approached asymptotic size. The growth constant (K) for C. gigas in the San Diego River was comparable to measurements in the Wadden Sea and parts of Europe (Van Der Veer 2006; Schmidt et al. 2008), ranging between 0.300 to $0.999 \mathrm{yr}^{-1}$. In other parts of Europe, the English Channel and along the Atlantic Coast of France, growth constants were between $0.365 \mathrm{yr}^{-1}$ to $1.304 \mathrm{yr}^{-1}$ (Lartaud et al. 2010), while rates from China were between $0.02 \mathrm{yr}^{-1}$ to $0.33 \mathrm{yr}^{-1}$ (Harding and Mann 2006). For O. lurida, this is one of the very first studies to calculate the growth constant (K) of O. lurida using the Von Bertalanffy growth model. While some potential problems with the VBGF are recognized (Newkirk 1981, Pardo et al. 2013), such as lack of ability to account for inter-annual variations in growth rates, it is a widely-used method that allows basic growth parameters to be compared (Katsanevakis and Maravelius 2008).

Like growth lines of a tree, growth lines in bivalve species have been used as a measurement of age (Richardson et al. 1993; Peharda et al. 2002; Harding and Mann 2006). Although C. gigas lived higher in the intertidal, analyses of growth lines demonstrate decreasing growth rates with increasing elevations. This could be due to the environmental stress (e.g. desiccation) as well as more limited time for feeding with increasing elevations (Borrero 1987; Bartol et al. 1999, Montalto and Drago 2003). For these analyses, it was assumed that growth lines represented annual growth marks, and this assumption is supported from work done elsewhere (Richardson et al. 1993a; 1993b; Kirby et al. 1998; Harding and Mann 2006). Crassostrea gigas found in the mid- and low-intertidal in the San 
Diego River shared similar relationships between growth lines and mean sizes lengths to individuals found in Washington, Oregon, California and China (Langdon and Robinson 1998; Harding and Mann 2006). Individuals with one growth line were between the range of 31-50mm, two growth lines between 85-90 mm, and three between 102-113 mm (Fig. 2.11). However, they are dwarfed by oysters in Korea, where C. gigas reached $70 \mathrm{~mm}$ within their first growth year (Mondol et al. 2016). Crassostrea gigas in Portugal and Mexico on the other hand, averaged smaller lengths resembling those found in the high tide zone of the San Diego River reaching size of 20-30 mm in their first year and 60-70 mm within their second growth year (Arizpe 1996; Almeida et al. 1998).

It is important to note that even though it was assumed that growth lines were laid down annually in the San Diego River, comparison of C. gigas growth in different zones would be valid if rings are laid at comparable times across zones (e.g., in association with events such as El Niños, Rollins et al. 1987). In this case, growth would be relative rather than annual. Due to the ecological and economic importance of C. gigas, and the potential for growth lines to provide valuable information about the species, more work is needed on growth rings both locally and in other regions. Since there has been very little work using rings to analyze age in C. gigas, along with the difficulty of reading them, more research should be conducted. For example, in many of the oysters examined in this study, large amounts of dirt were found within the matrix of the shell, indicating that the layers had to be laid down relatively quickly for the mud not to get washed away. 
Alternative ways of measuring growth should also be attempted through mark and recapture, or chemical marking.

The goal of this research was to increase understanding of the current population and growth of C. gigas and O. lurida in Southern California. Despite a highly urbanized river mouth with muted tidal flushing, actual tidal zonation range of both species was similar to other areas with well flushed systems. Even though C. gigas tended to have higher densities in the higher tidal zones, they still had a decrease in growth rate compared to C. gigas growing in the lower tidal zones. Growth rates of both species were found to be very similar, even though $C$. gigas tends to grow to a much larger size than $O$. lurida.

The hope is to lay a foundation of baseline scientific information against which future change can be assessed and to inform future research directions, such as a focus on how each species interacts independently with their environment and with one another. Throughout the study, there were many unmeasured factors that could influence the densities and growth of both species, like temperature, salinity and pH. For example, in previous studies done in Spain, temperature was a strong influence on gametogenesis and recruitment success for C. gigas (Ruiz et al. 1992). Understanding recruitment and substrate preference for each species is important for both oyster restoration and management. During this study it was observed that many of the O. lurida collected were found residing on the shells of larger $C$. gigas (both alive and dead). This is not uncommon, as $C$. gigas shells provide hard substrate for other native species (Troost 2010). They have even been used as a recruitment tool for O. lurida, in 
Washington State. For example, White et al. (2009) found there was no significant difference in O. lurida settlement preference between C. gigas shells (crushed and whole) and O. lurida shells (crushed and alive). Through this research and the methods used to measure the growth and distribution of both species, there is now a clearer picture of these ecologically and economically important species in Southern California. 
A)

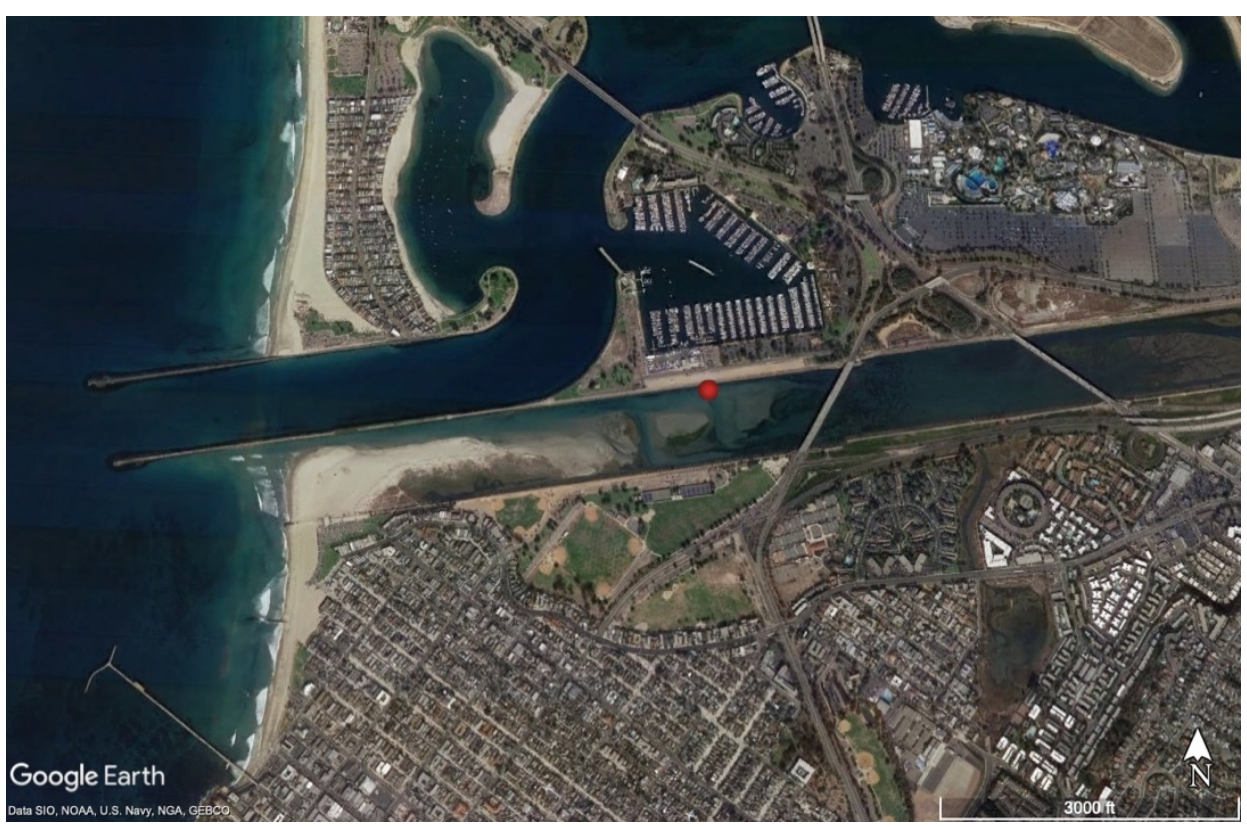

B)

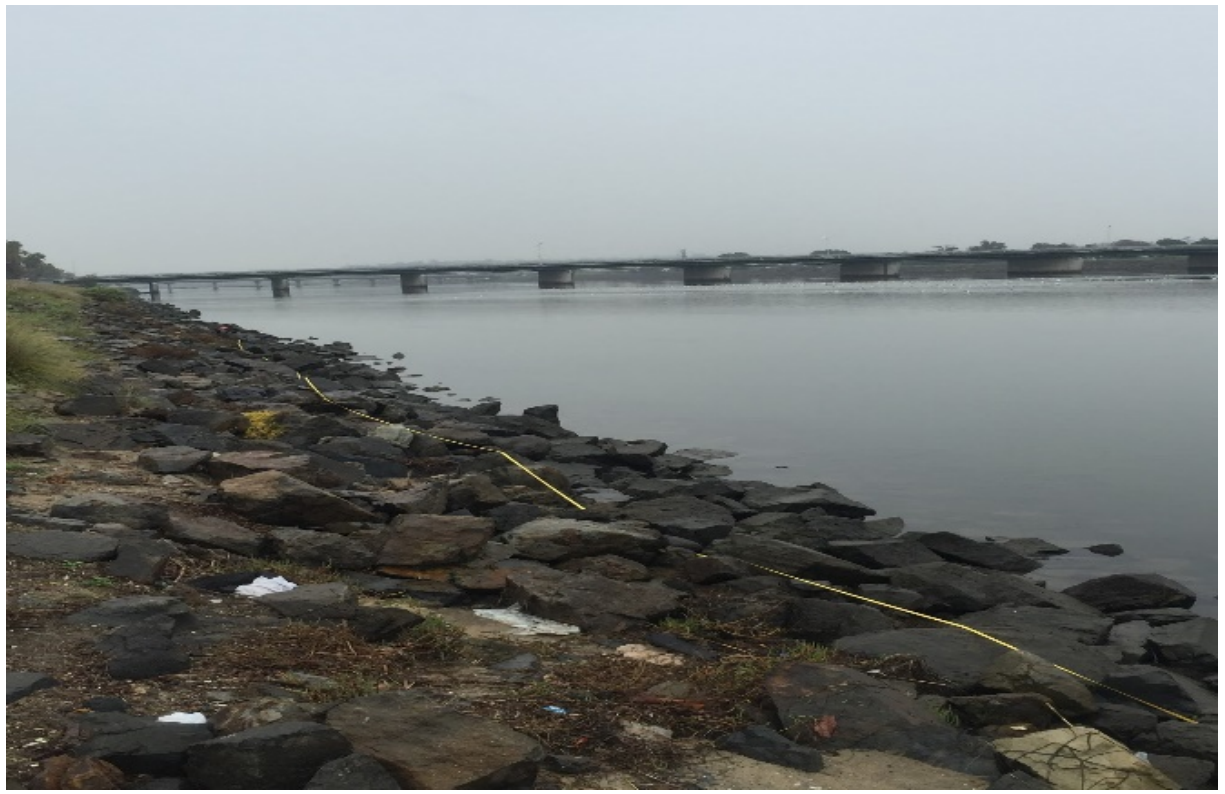

Figure 2.1. A) Map of study site (red dot) in the San Diego River, and B)

photograph of transect along rip-rap bank of the San Diego River channel, facing upstream. 
A)

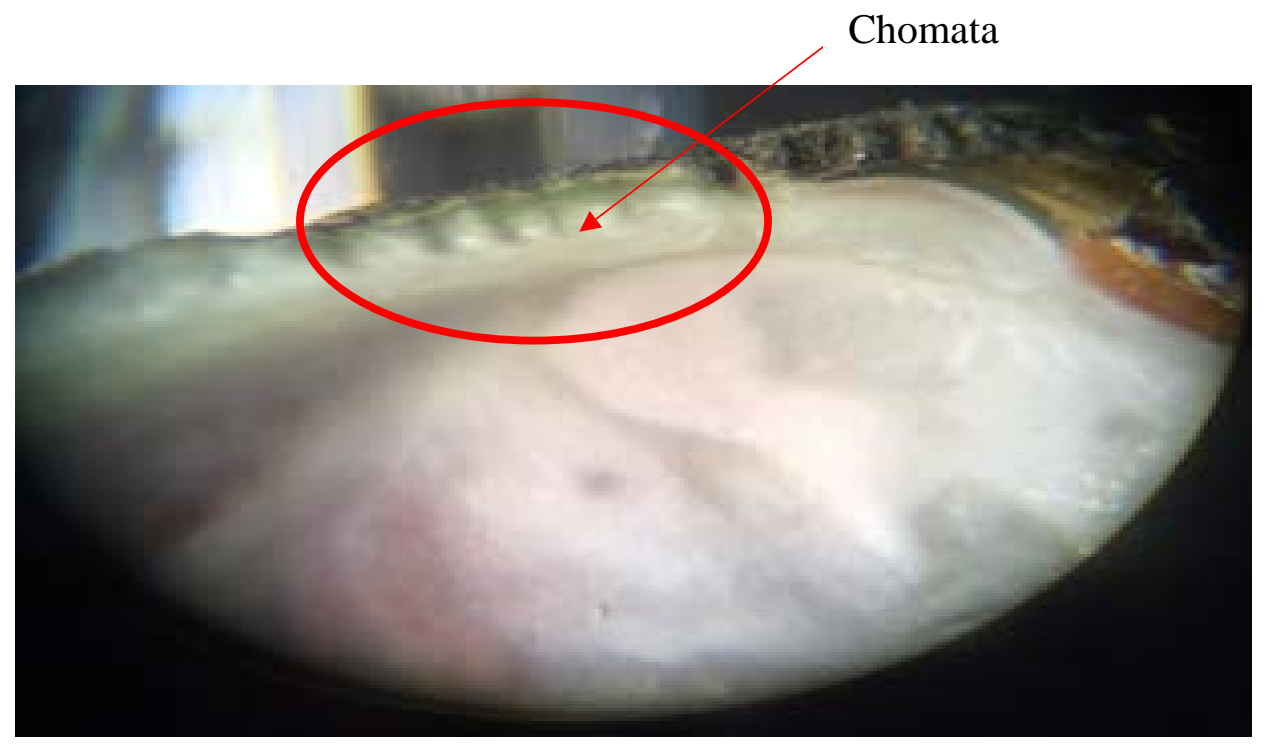

B

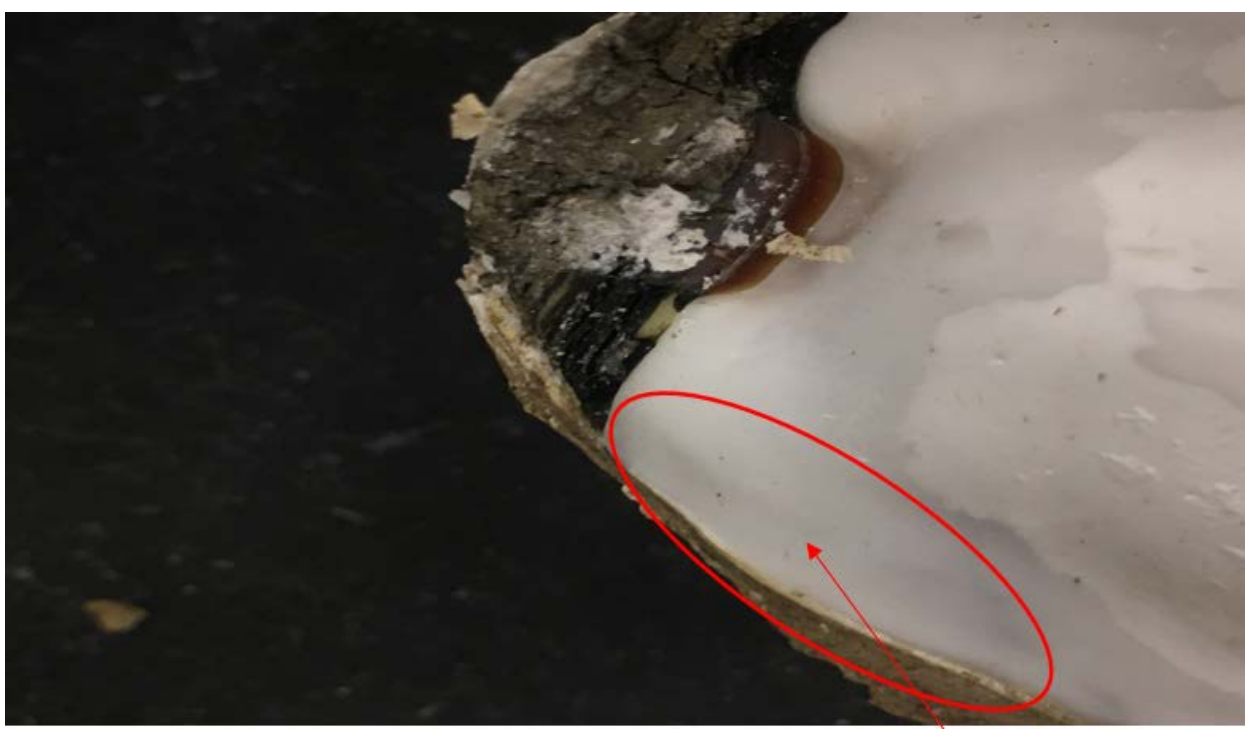

No Chomata

Figure 2.2. A) Detail of the chomata (grooves near umbo) found in Ostrea lurida.

(B) Umbo of Crassostrea gigas, with the absence of chomata. 


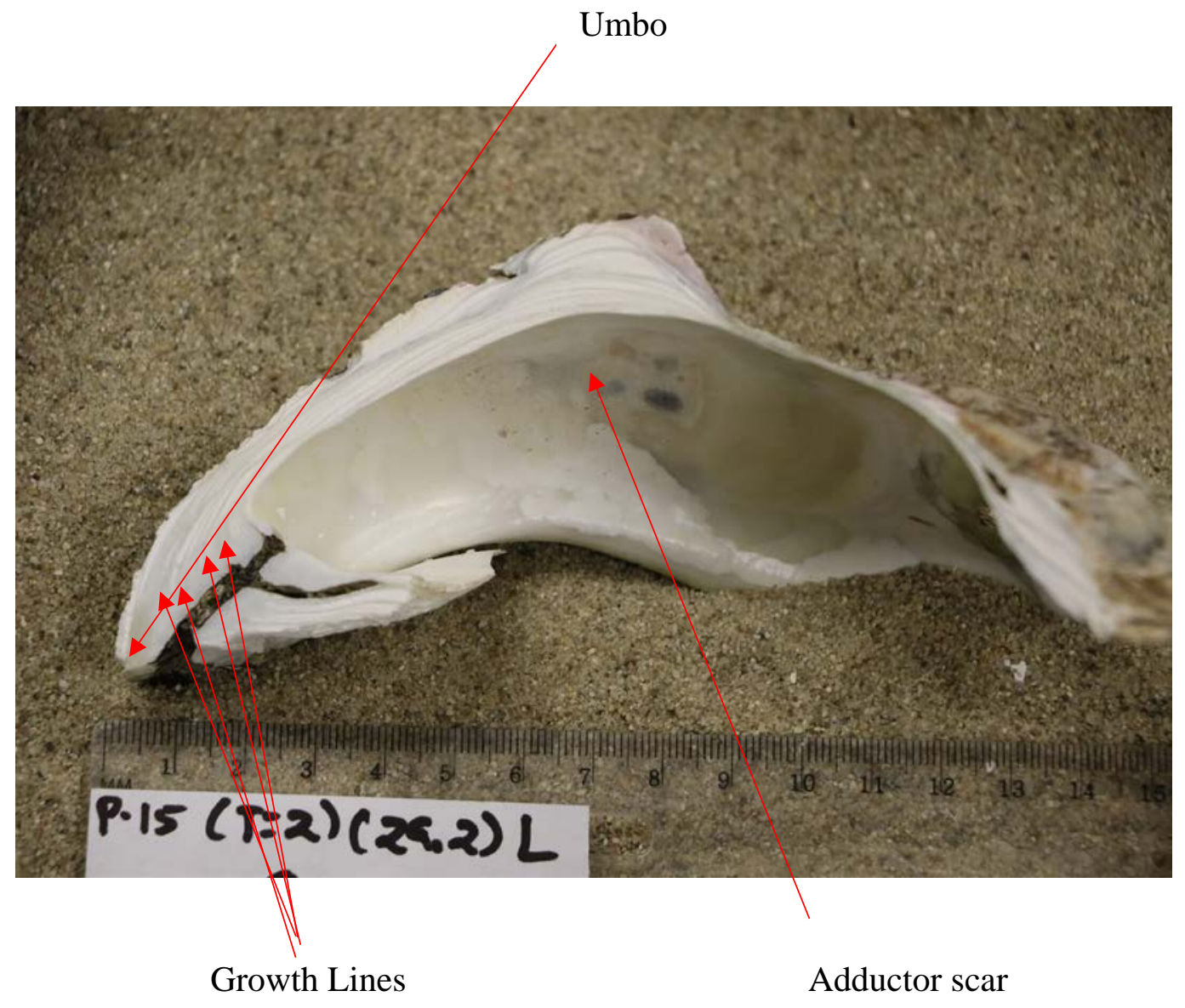

Figure 2.3. Cross section of Crassostrea gigas, displaying grey growth lines running through the interior of the shell. 


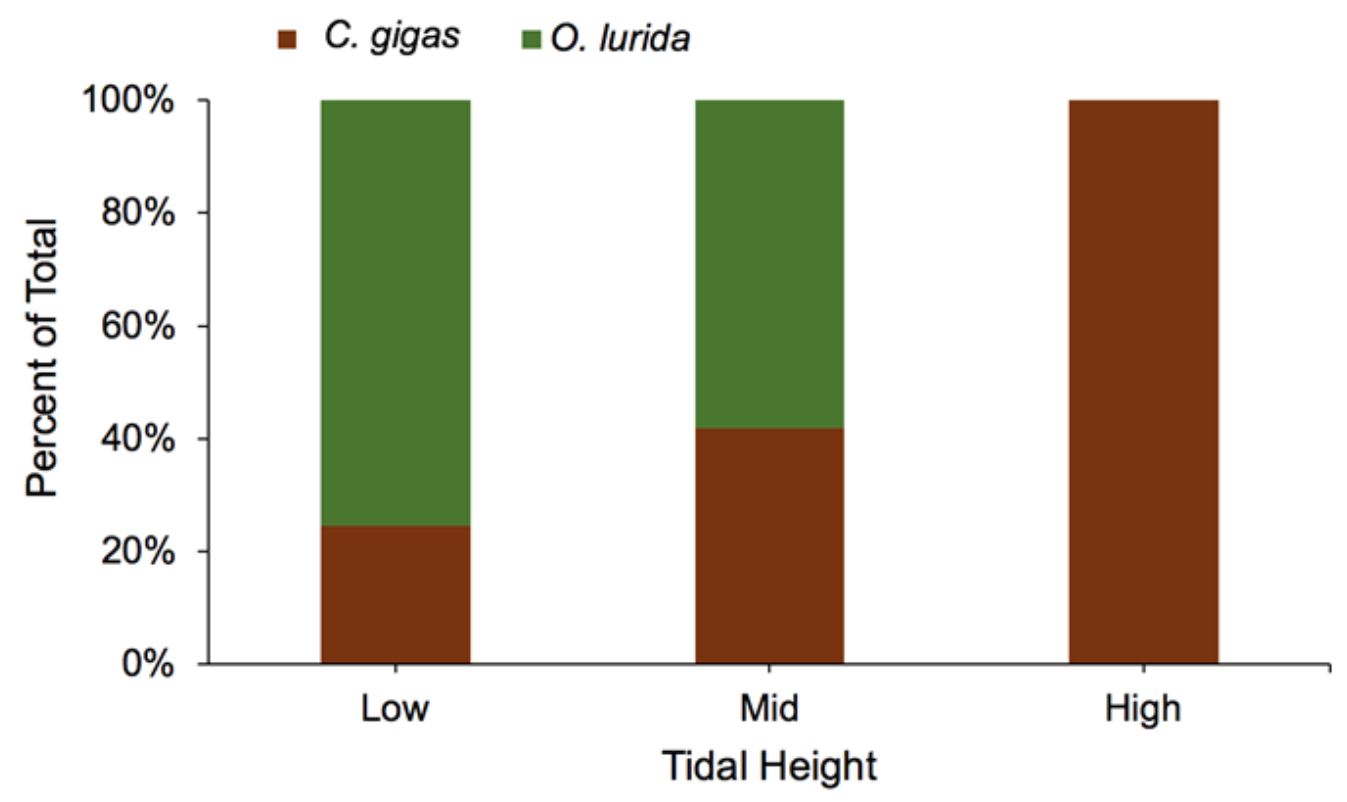

Figure 2.4. Percentages of Ostrea lurida and Crassotrea gigas in the high-, midand low-intertidal zones in the San Diego River. 
A)

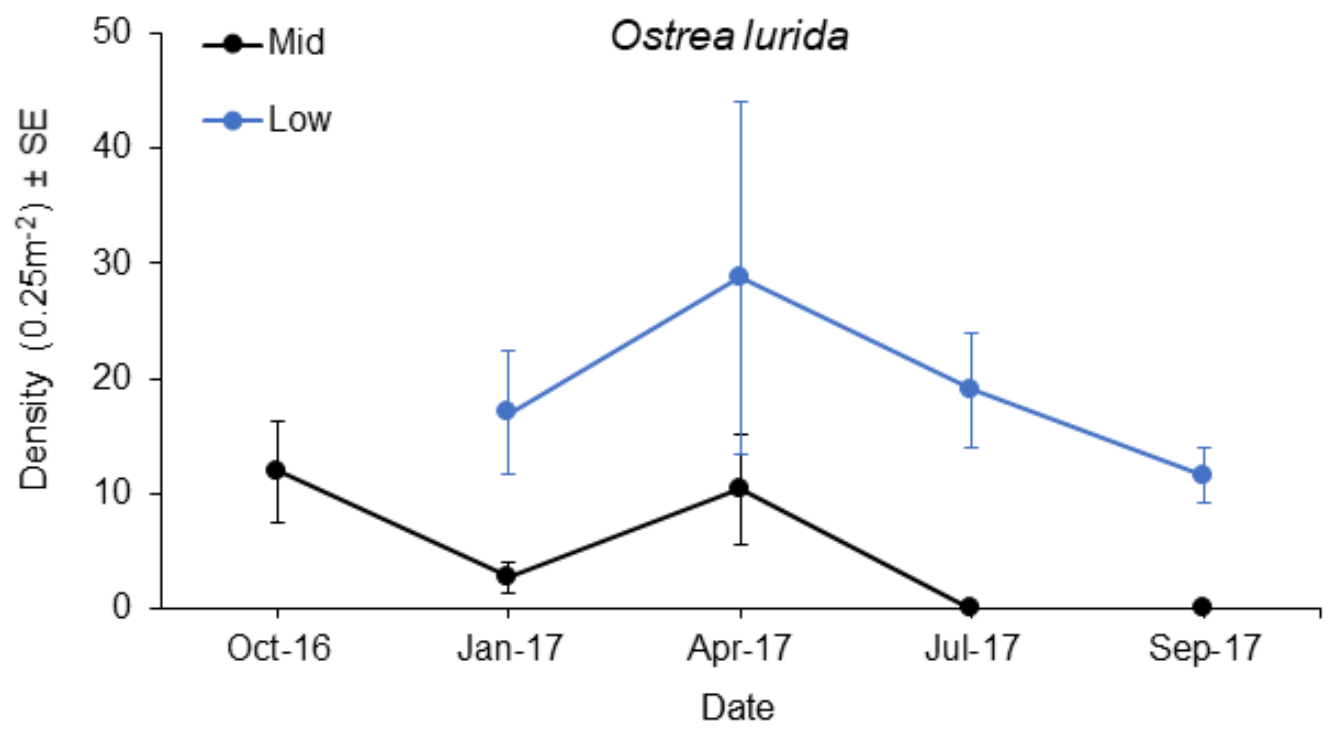

B)

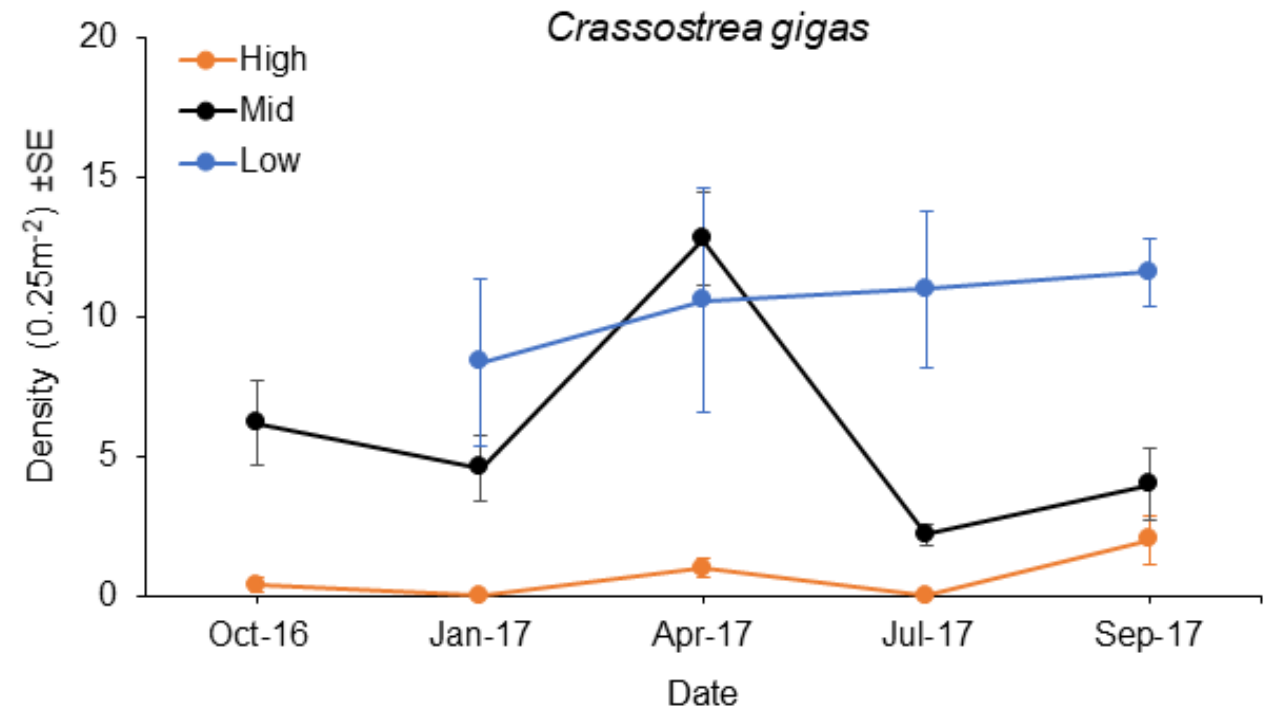

Figure 2.5. Mean densities of A) Ostrea lurida and B) Crassostrea gigas in the San Diego River. 


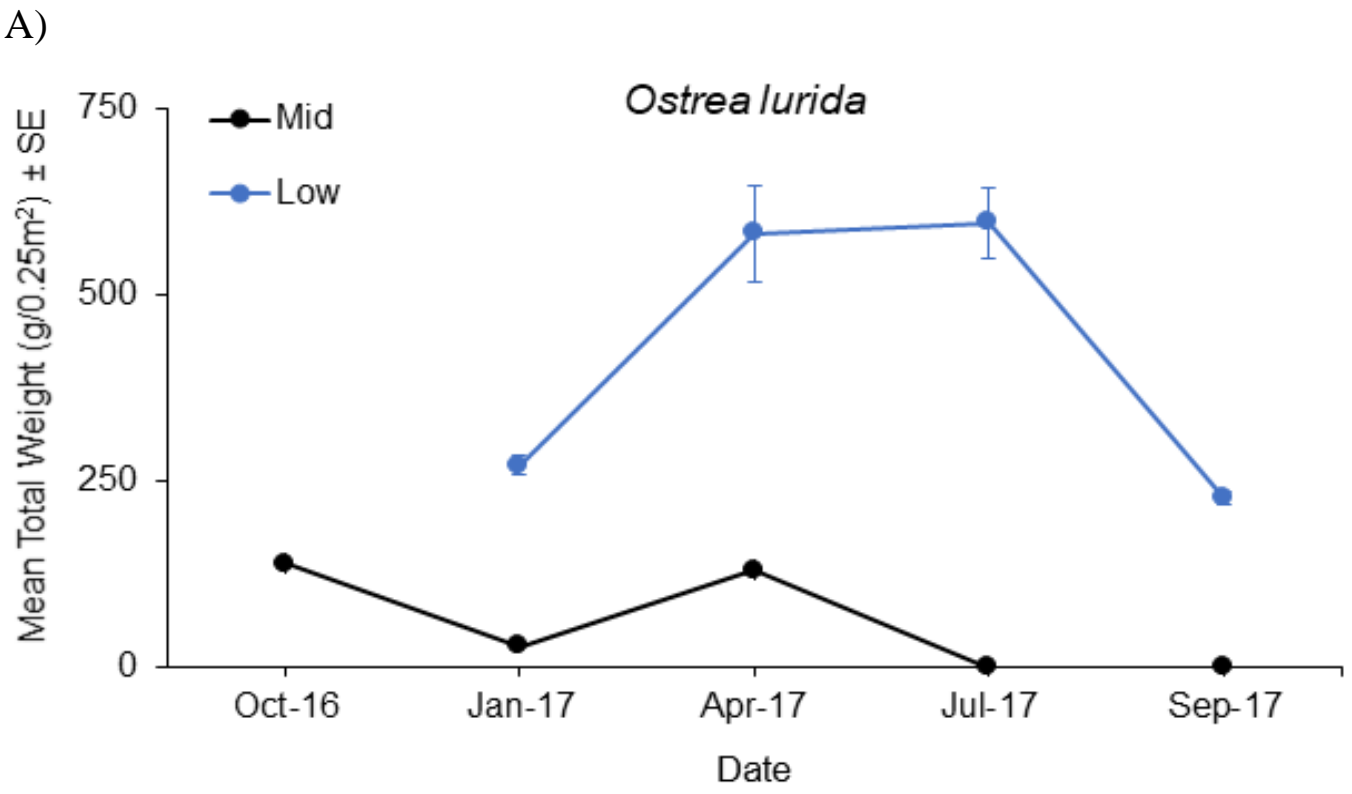

B)

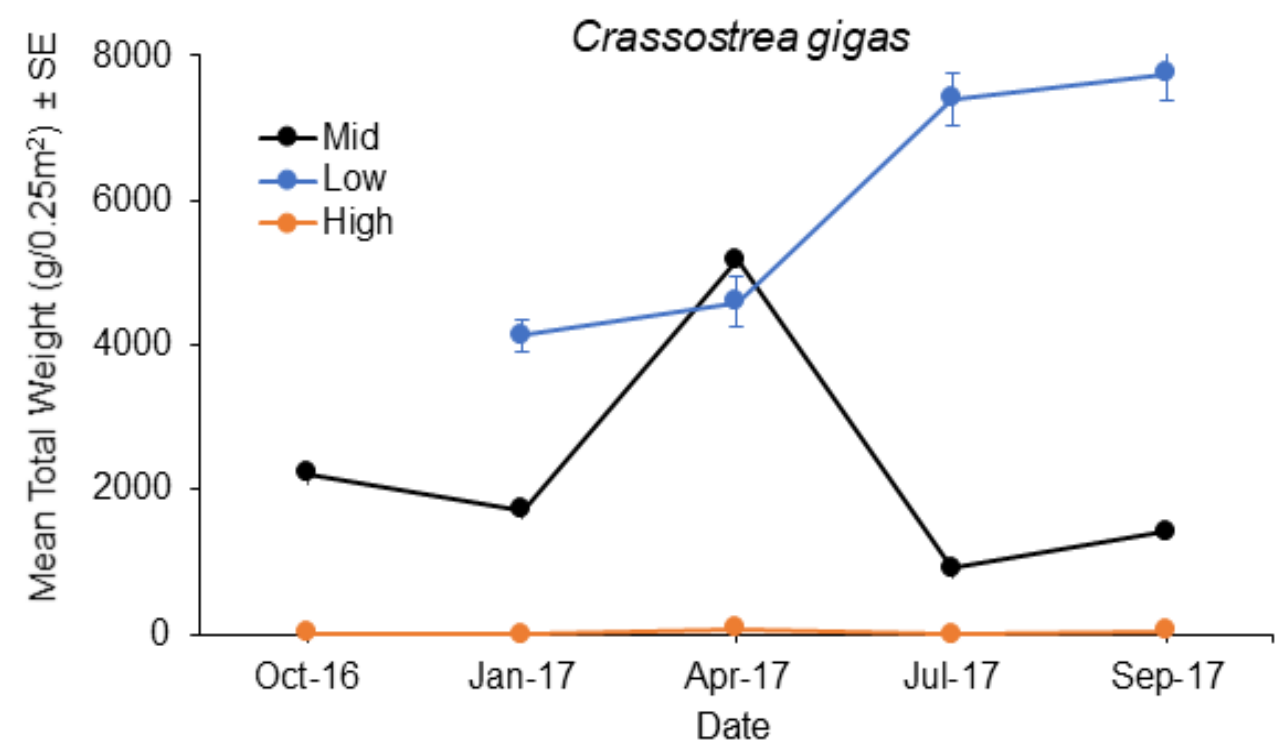

Figure 2.6. Mean total biomass (shell weight plus dry tissue weight) of A) Ostrea lurida and B) Crassostrea gigas in the San Diego River. 
A)

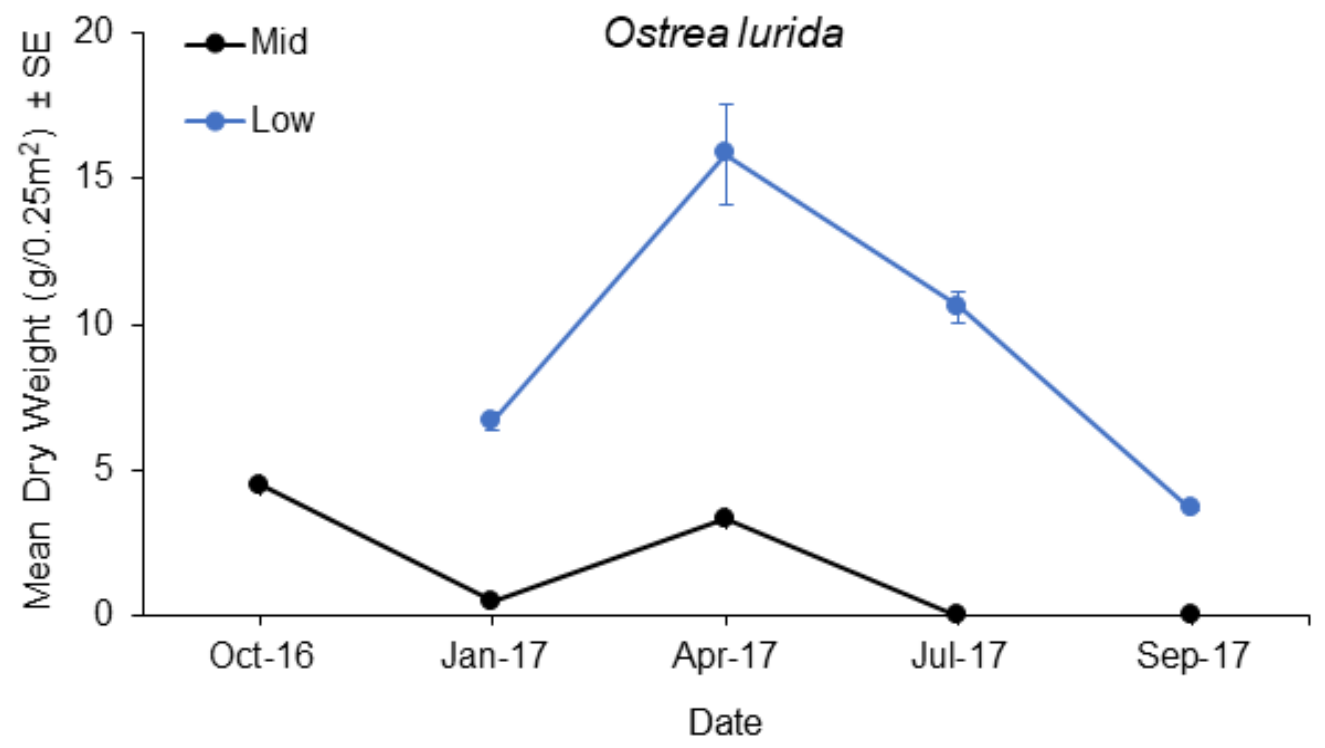

B)

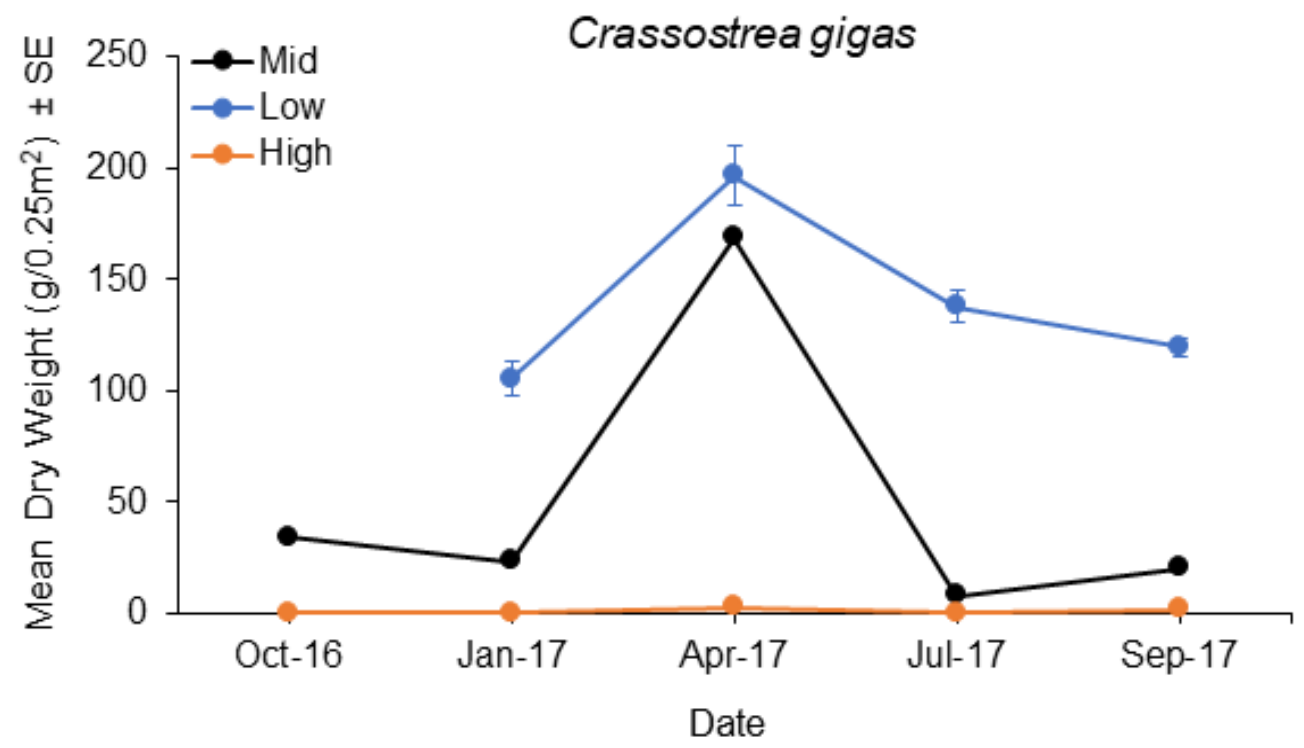

Figure 2.7. Mean dry weights (tissue) of A) Ostrea lurida and B) Crassostrea gigas in the San Diego River. 


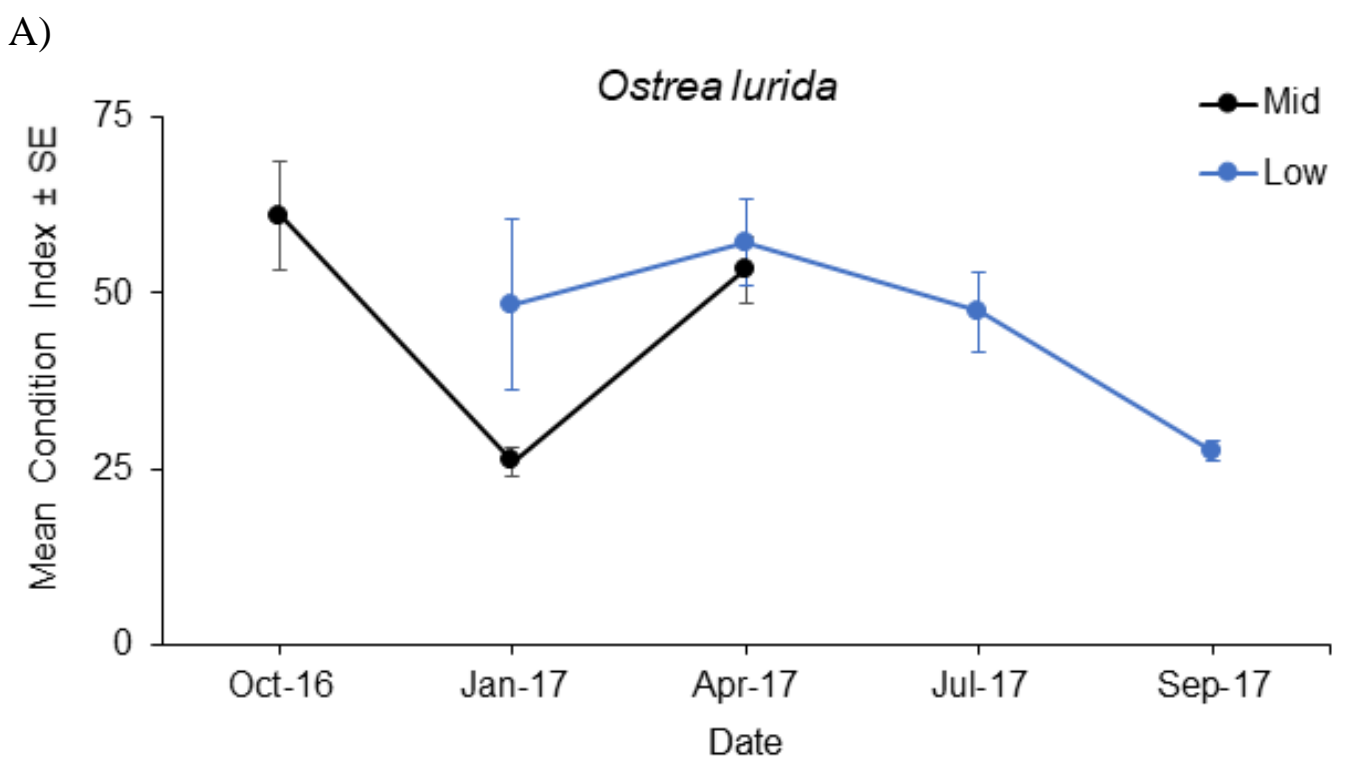

B)

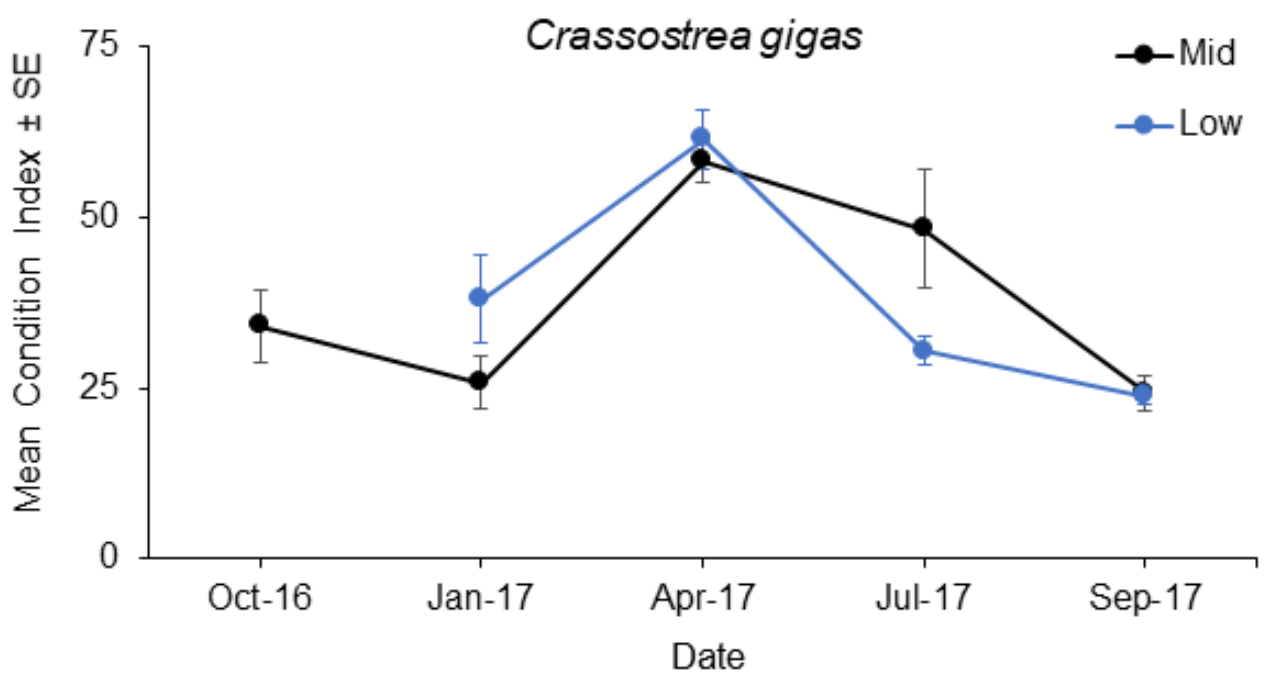

Figure 2.8. Mean Condition Index (1000 x dry tissue weight / shell weight) for A) Ostrea lurida and B) Crassostrea gigas in the San Diego River. 

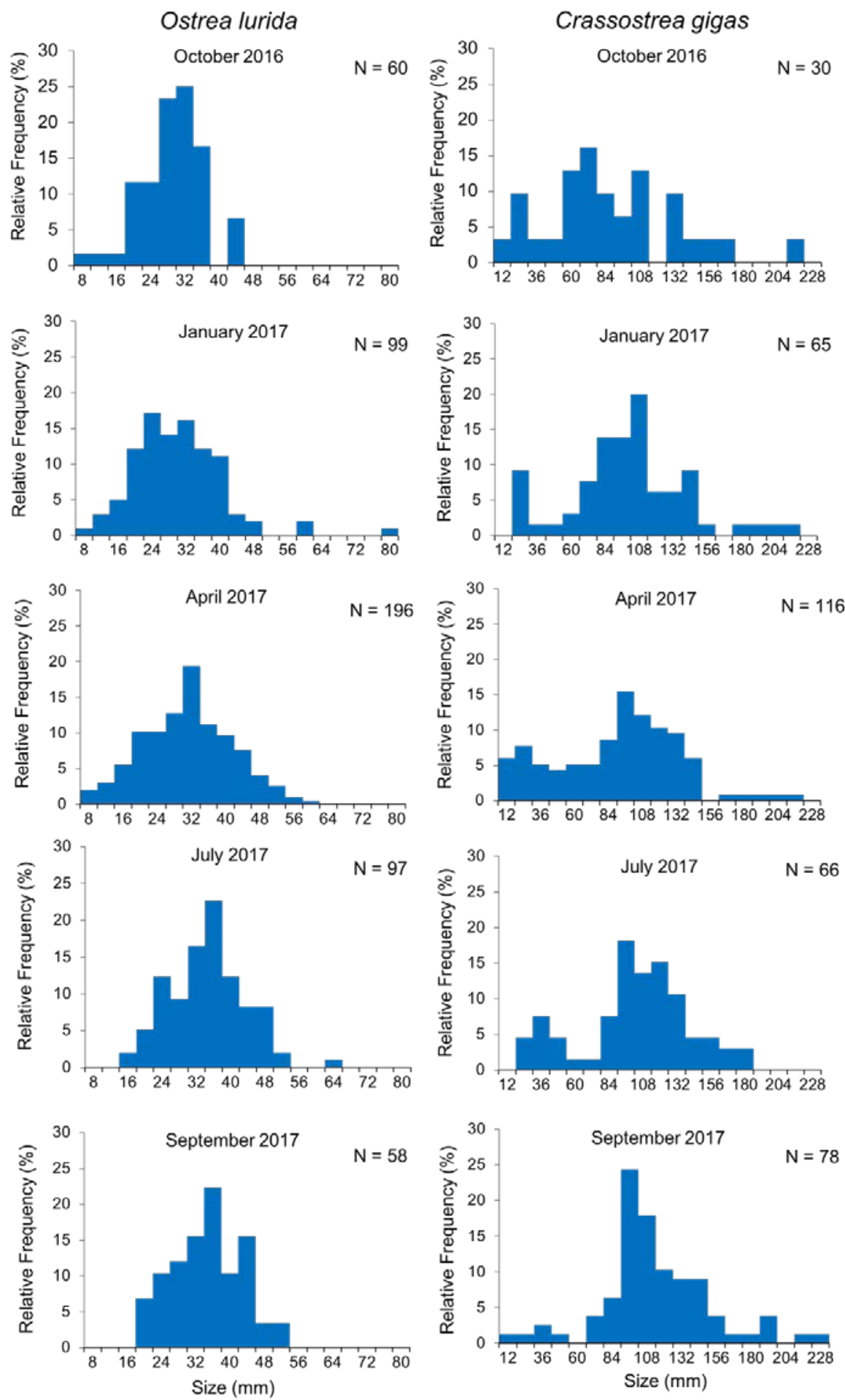

Figure 2.9. Length frequency distributions for Ostrea lurida and Crassostrea gigas in the San Diego River. $\mathrm{N}=$ total number of individuals. 
A)

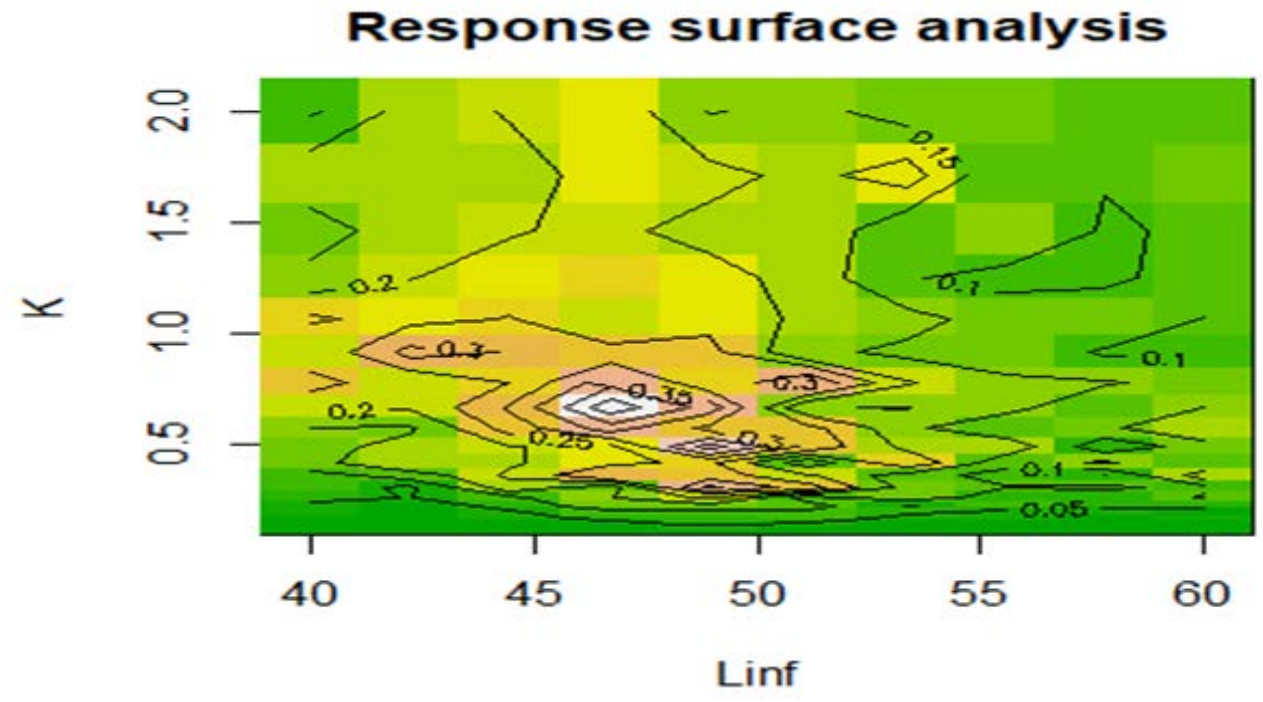

B)

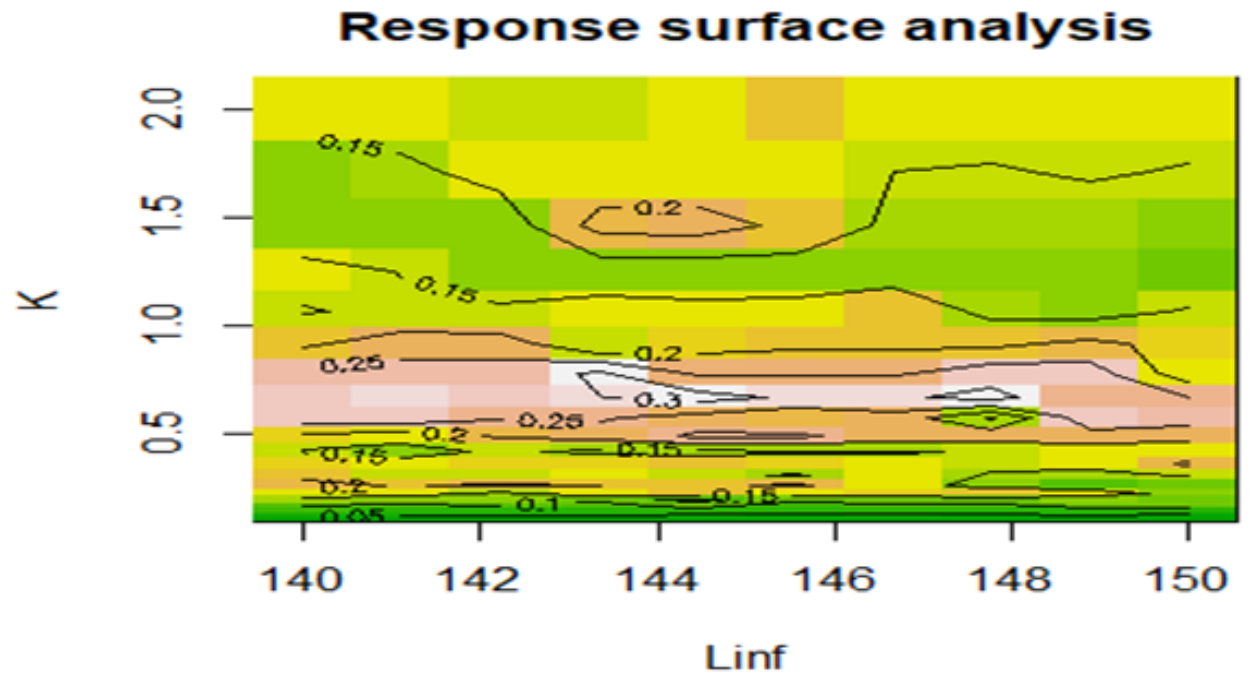

Figure 2.10. Response Surface Analysis using ELEFAN to calculate growth rates (K) and asymptotic size (Linf) of the Van Bertalanffy Growth Function for A) Ostrea lurida and (B) Crassostrea gigas. 


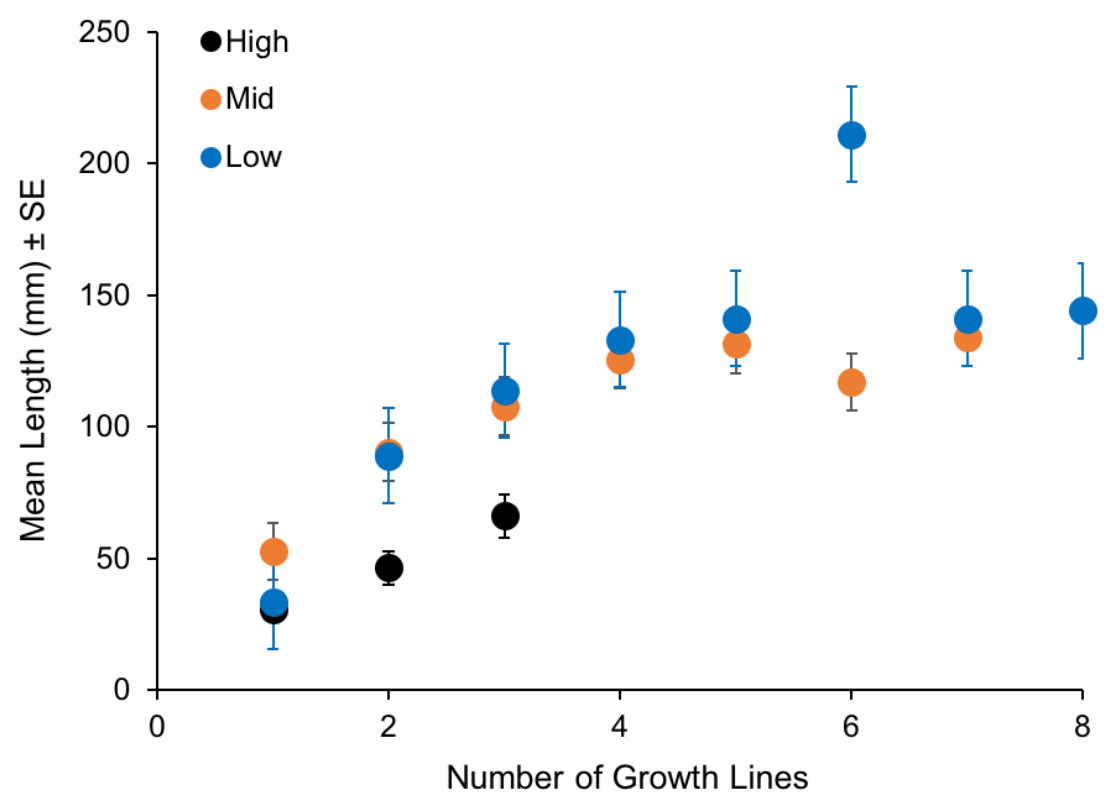

Figure 2.11. Mean length vs. number of growth lines for Crassostrea gigas in the high-, mid-, and low-intertidal. 


\subsection{Literature Cited}

Almeida, M. Machado, J. Coimbra, J. (1998). "Growth and biochemical composition of Crassostrea gigas (Thunberg) at three fishfarm earthern ponds." Journal of Shellfish Research 16: 455-462.

Arakawa, K. Y. (1990). "Commercially important species of oysters in the world." Marine \& Freshwater Behaviour \& Physiology 17(1): 1-13.

Arizpe, O. (1996). "Secondary production, growth and survival of the Pacific oyster Crassostrea gigas (Thunberg) in tropical waters, Bahia de la Paz, Mexico." Journal of Shellfish Research 15(3): 601-607.

Baker, P. (1995). "Review of ecology and fishery of the Olympia oyster, Ostrea lurida with annotated bibliography." Journal of Shellfish Research 14(2): 501518.

Bartol, I. K., and R. Mann (1999). Growth and mortality of oysters (Crassostrea virginica) on constructed intertidal reefs: effects of tidal height and substrate level. Journal of Experimental Marine Biology and Ecology 181:239-253.

Bishop, M. J., Krassoi, F. R, McPherson R.G. (2010). "Change in wild-oyster assemblages of Port Stephens, NSW, Australia, since commencement of non- 
native Pacific oyster (Crassostrea gigas) aquaculture." Marine and Freshwater Research 61(6): 714-723.

Borrero, F. J. (1987). "Tidal height and gametogenesis: reproductive variation among populations of Geukensia demissa." The Biological Bulletin 173(1): $160-168$.

Brumbaugh, R. D. and L. D. Coen (2009). "Contemporary approaches for smallscale oyster reef restoration to address substrate versus recruitment limitation: a review and comments relevant for the Olympia oyster, Ostrea lurida Carpenter 1864." Journal of Shellfish Research 28(1): 147-162.

Canada, L. A (2006). "Sitting on the Dock of the Bay” 100 years of Photographs from the San Diego Historical Society.” The Journal of San Diego History 52 (1\&2): 1-17.

Carlton, J. T. (1979). "History, biogeography, and ecology of the introduced marine and estuarine invertebrates of the Pacific Coast of North America." Ph.D. thesis, Univ. of California, Davis.

Carson, H. S. (2010). "Population connectivity of the Olympia oyster in southern California." Limnology and Oceanography 55(1): 134-148. 
Crooks, J. A. (2001). "Assessing invader roles within changing ecosystems: historical and experimental perspectives on an exotic mussel in an urbanized lagoon." Biological Invasions 3(1): 23-36.

Crooks J.A., Crooks K.R., and Crooks, A.J. (2015) “Observations of the nonnative Pacific oyster (Crassostrea gigas) in San Diego County, California”. California Fish and Game 101:101-107.

Crooks, S. and Turner, R (1999). "Integrated coastal management: sustaining estuarine natural resources." Advances in Ecological Research 29: 241-289.

Diederich, S., Nehls, G., var Beusekom, J. E. E, Reise, K. (2005). "Introduced Pacific oysters (Crassostrea gigas) in the northern Wadden Sea: invasion accelerated by warm summers?" Helgoland Marine Research 59(2): 97-106.

Dinamani, P. (1971). "Occurrence of the Japanese oyster, Crassostrea gigas (Thunberg), in northland, New Zealand." New Zealand Journal of Marine and Freshwater Research 5(2): 352-357.

Fodrie, F. J., Rodriguez, A., Gittman, R., Grabowski, J., Lindquist, N., Peterson, C., Piehler, M., and Ridge, J. (2017). "Oyster reefs as carbon sources and sinks." Proceedings of the Royal Society B: Biological Sciences 284(1859): 891. 
Groth, S. and S. Rumrill (2009). "History of Olympia oysters (Ostrea lurida Carpenter 1864) in Oregon estuaries, and a description of recovering populations in Coos Bay." Journal of Shellfish Research 28(1): 51-58.

Harding, J. M. and R. Mann (2006). "Age and growth of wild Suminoe (Crassostrea ariakensis, Fugita 1913) and Pacific (C. gigas, Thunberg 1793) oysters from Laizhou Bay, China." Journal of Shellfish Research 25(1): 73-82.

Harris, J. (2008). "Pacific oyster, Crassostrea gigas (Thunberg, 1793)." Aquatic Invasive Species Profile. Aquatic Invasion Ecology.

Katsanevakis. Stelios, and Christos D. Maravelias (2008). "Modelling fish growth: multi-model inference as a better alternative to a priori using von Bertalanffy equation." Fish and Fisheries 9(2): 178-187.

Kirby X.M., Soniat T.M., and Spero H.J. (1998) “Stable isotope sclerochronology of Pleistocene and Recent oyster shells (Crassostrea virginica).” Palaios 13:560-569. 
Kochmann, J., Buschbaum C., Volkenborn N., Reise K. (2008). "Shift from native mussels to alien oysters: differential effects of ecosystem engineers." Journal of Experimental Marine Biology and Ecology 364(1): 1-10.

Krassoi, F. R., et al. (2008). "Condition-specific competition allows coexistence of competitively superior exotic oysters with native oysters." Journal of Animal Ecology 77(1): 5-15.

Langdon, C. and A. Robinson (1996). "Aquaculture potential of the Suminoe oyster (Crassostrea ariakensis Fugita 1913)." Aquaculture 144(4): 321-338.

Lartaud, F., de Rafélis, M., Ropert, M., Emmanuel, L., Geairon, P., Renard, M. (2010). "Mn labelling of living oysters: artificial and natural cathodoluminescence analyses as a tool for age and growth rate determination of C. gigas (Thunberg, 1793) shells." Aquaculture 300(1-4): 206-217.

Mann, R. and S. Glomb (1978). "The effect of temperature on growth and ammonia excretion of the Manila clam Tapes japonica." Estuarine and Coastal Marine Science 6 (3): 335-339.

Merkel \& Associates, inc, Project manager Holly Henderson (2015). “San Diego Bay Native Oyster Resoration Plan.” State of California Coastal Conservancy. 
Mondol MR, Kim CW, Kang CK, Park SR, Noseworthy RG, Choi KS (2016).

"Growth and reproduction of early grow-out hardened juvenile Pacific oysters, Crassostrea gigas in Gamakman Bay, off the south coast of Korea.” Aquaculture 463: 224-233.

Montalto, L. and I. E. De Drago (2003). "Tolerance to desiccation of an invasive mussel, Limnoperna fortunei (Dunker, 1857) (Bivalvia, Mytilidae), under experimental conditions." Hydrobiologia 498(1-3): 161-167.

Newkirk, G.F. (1981). “On the unpredictability of bivalve growth rates: is a slow growing juvenile oyster a runt for life?, in : Claus, C. et al. (Ed.). Nursery Culturing of Bivalve Molluscs: Proceedings of the International Workshop on Nursery Culturing of Bivalve Molluscs Ghent, Belgium, 24-26 February 1981.” European Mariculture Society Special Publication, 7, 211-218.

Newell, R. I. and E. W. Koch (2004). "Modeling seagrass density and distribution in response to changes in turbidity stemming from bivalve filtration and seagrass sediment stabilization." Estuaries 27(5): 793-806.

Padilla, D. K. (2010). "Context-dependent impacts of a non-native ecosystem engineer, the Pacific oyster Crassostrea gigas." Integrative and Comparative Biology 50(2): 213-225. 
Papageorge, N. T. (1971). "The role of the San Diego River in the development of Mission Valley." The Journal of San Diego History 17(2): 1-24.

Pardo, S. Cooper. AB. Dulvy, NK. (2013). "Avoiding fishy growth curves." Methods in Ecology and Evolution 4(4): 353-360.

Pauly, D. (1987). “A review of the ELEFAN system for analysis of lengthfrequency data in fish and aquatic invertebrates.” ICLARM conference proceedings / International Center for Living Aquatic Resources Management 13: 7-34.

Peharda, M., Richardson, C.A., Onofri, V., Bratos, A. \& Crncevic, M. (2002). "Age and growth of the bivalve Arca noae L. in the Croatian Adriatic Sea." Journal of Molluscan Studies, 68: 307- 310.

Peter-Contesse, T. \& B. Peabody (2005). "Reestablishing Olympia oyster populations in Puget Sound, Washington.” Washington Sea Grant Program. $1-8$.

Polson, M. P., Hewson W.E., Eernisse D.J., Baker P.K. and Zacherl D.C. (2009). "You say conchaphila, I say lurida: molecular evidence for restricting the Olympia oyster (Ostrea lurida Carpenter 1864) to temperate western North America." Journal of Shellfish Research 28(1): 11-21. 
Polson, M. P. and D. C. Zacherl (2009). "Geographic distribution and intertidal population status for the Olympia oyster, Ostrea lurida Carpenter 1864, from Alaska to Baja." Journal of Shellfish Research 28(1): 69-78.

Pritchard, C., Shanks A., Rimler R., Oates M. and Rumrill S. (2015). "The Olympia oyster Ostrea lurida: recent advances in natural history, ecology, and restoration." Journal of Shellfish Research 34(2): 259-272.

Pryde, P. R. (2002). "The Day the San Diego River Was Saved: The History of Floods and Floodplain Planning in Mission Valley." The Journal of San Diego History 156-157.

Richardson, C. A., Collis, S. A., Ekaratne, K., Dare, P. \& Key, D. (1993). “The age determination and growth rate of the European flat oyster, Ostrea edulis, in British waters determined from acetate peels of Umbo growth lines.” ICES (International Council for the Exploration of the Sea) Journal of Marine Science 50:493-500.

Rollins, H. B., Sandweiss, D.H., Brand, U., and Rollins J.C. (1987). "Growth increment and stable isotope analysis of marine bivalves: Implications for the geoarchaeological record of El Niño." Geoarchaeology 2(3): 181-197. 
Ruesink JL, Lenihan HS, Trimble AC, Heiman KW, Micheli F, Byers JE, Kay MC. (2005). "Introduction of non-native oysters: Ecosystem effects and restoration implications.” Annual Review of Ecology Evolution and Systematics 36: 643-689.

Ruiz, C., Abad, M., Sedano, F., Garcia-Martin, L., Sa'nchez-Ló́pez, J. (1992). “Influence of seasonal environmental changes on the gamete production and biochemical composition of Crassostrea gigas (Thunberg) in suspended culture in El Grove, Galicia, Spain.” Journal of Experimental Marine Biology and Ecology. 155, $249-262$.

Schmidt, A., Wehrmann, A., Dittmann, S. (2008). "Population dynamics of the invasive Pacific oyster Crassostrea gigas during the early stages of an outbreak in the Wadden Sea (Germany).” Helgoland Marine Research 62, 367- 376.

Schwamborn R, Mildenberger TK, Taylor M. (2019). “Assessing sources of uncertainty in length-based estimates of body growth in populations of fishes and macroinvertebrates with bootstrapped ELEFAN.” Ecological Modelling. 393:37-51. 
Shatkin, G. (1997). "Considerations regarding the possible introduction of the Pacific oyster (Crassostrea gigas) to the Gulf of Maine: a review of global experience." Journal of Shellfish Research. 16: 463-478.

Swann L (2008). “The use of living shorelines to mitigate the effects of storm events on Dauphin Island, Alabama, USA.” American Fisheries Society Symposium 64:47-57.

Torigoe, K. (1981). “Oysters in Japan.” Journal of Science of the Hiroshima University. Div. 1 (Zoology) 29(2):291-419.

Trimble AC, Ruesink JL, Dumbauld BR (2009). “Factors preventing the recovery of a historically overexploited shellfish species, Ostrea Lurida Carpenter 1864.” Journal of Shellfish Research 28:97-106.

Tronske, N. B., Parker, T. A., Henderson, H. D., Burnaford, J. L., \& Zacherl, D. C. (2018). “Densities and zonation patterns of native and non-Indigenous oysters in Southern California Bays.” Wetlands. 38(6): 1313-1326.

Troost, K. (2010). "Causes and effects of a highly successful marine invasion: case-study of the introduced Pacific oyster Crassostrea gigas in continental NW European estuaries." Journal of Sea Research 64(3): 145-165. 
Troost, K., Veldhuizen, R., Stamhuis, E. J., Wolff, W., J. (2008). “Can bivalve veligers escape feeding currents of adult bivalves?” Journal of Expirimental Marine Biology and Ecology 358:185-196.

Valdez, S., Peabody, B., Allen, B., Blake, B., Ruesink, J. (2017). “Experimental test of oyster restoration within eelgrass.” Aquatic Conservation Marsh Freshwater. Ecosystems 27: 578-587.

Wasson, K., C. Zabin, J. Bible, S. Briley, E. Ceballos, A. Chang, B. Cheng, A. Deck, T. Grosholz, A. Helms, M. Latta, B. Yednock, D. Zacherl, and M. Ferner (2015). “A guide to Olympia oyster restoration and conservation: environmental conditions and sites that support sustainable populations. Climate Change and Olympia Oysters.” http://www.sfbaysubtidal.org/OYSTERGUIDE-FULL-LORES. pdf. Accessed 18 Nov 2015.

Wehrmann, A., M. Herlyn, F. Bungenstock, G. Hertweck, AND G. Millat (2000). "Distribution gap is closed -- first record of naturally settled Pacific oysters Crassostrea gigas in the East Frisian Wadden Sea, North Sea.” Helgoland Marine Research 30: 153-160.

White, J. M., Buhle, E. Ruesink, J, Trimble, A. (2009). "Evaluation of Olympia oyster (Ostrea lurida carpenter 1864) status and restoration techniques in 
Puget sound, Washington, United States." Journal of Shellfish Research 28(1): 107-113.

Wrange AL, Valero J, Harkestad LS, Strand O, Lindegarth S, Christensen HT, Dolmer P, Kristensen PS, Mortensen S. (2010). "Massive settlements of the Pacific oyster, Crassostrea gigas, in Scandinavia.” Biological Invasions 12: 1453-1458. 


\section{CONCLUSIONS}

This study on native and invasive oysters in the San Diego River demonstrated that although Crassostrea gigas had invaded this system, Ostrea lurida was found in higher abundances. Relative growth rates of the two species were similar, but because of the much larger size of C. gigas, its total biomass in the intertidal was much higher. Both species decreased in abundance with tidal height, but $C$. gigas decreased less dramatically and was found at higher elevations. These results demonstrate that although native oysters are persisting despite the Pacific oyster invasion, although there is the potential for negative interactions in zones of overlap in the intertidal.

These results provide a foundation of baseline information that can help inform future research on these two species. Potential topics could include:

- Longer-term tracking of these two species, especially since the invasion of C. gigas is relatively recent.

- Using other methodologies to assess growth rates, such as chemical tagging and mark / recapture techniques.

- Assessing spawning and recruitment patterns for the two species

- Characterizing the role of physical parameters, such as temperature and salinity, on oyster demography.

- Observational and experimental studies of competition between $C$. gigas and $O$. lurida.

Continued research such as this should further enhance our ability to understand and potentially manage these shellfish in San Diego's coastal waters. 


\section{APPENDiX 1. SHELL MORPHOLOGY}

Summary of morphological charactersitics of Crassostrea gigas and Ostrea lurida from the San Diego River. Measurements were made for shell height (SH), shell width (SW), and shell inflation (depth) (SI). Ranges for each measurement are presented, as well as the ratio between $\mathrm{SH}$ :SW and SH:SI and their standard error $(\mathrm{SE})$.

\begin{tabular}{|l|l|l|l|l|l|l|l|}
\hline $\begin{array}{l}\text { Tidal } \\
\text { Height }\end{array}$ & Species & $\mathrm{n}$ & $\begin{array}{l}\text { SH } \\
\text { Range } \\
(\mathrm{mm})\end{array}$ & $\begin{array}{l}\text { SW } \\
\text { Range } \\
(\mathrm{mm})\end{array}$ & $\begin{array}{l}\text { SI } \\
\text { Range } \\
(\mathrm{mm})\end{array}$ & $\begin{array}{l}\text { Average } \\
\text { SH-SW } \\
\text { Ratio (SE) }\end{array}$ & $\begin{array}{l}\text { Average } \\
\text { SH-SI } \\
\text { Ratio (SE) }\end{array}$ \\
\hline High & C. gigas & 17 & $18-82$ & $15-52$ & None & $1.31(0.09)$ & None \\
\hline $\begin{array}{l}\text { High } \\
\text { intertidal }\end{array}$ & O. lurida & 0 & None & None & None & None & None \\
\hline $\begin{array}{l}\text { Mid } \\
\text { intertidal }\end{array}$ & C. gigas & 148 & $9-213$ & $7-99$ & $3-73$ & $1.67(0.03)$ & $4.08(0.02)$ \\
\hline $\begin{array}{l}\text { Mid } \\
\text { intertidal }\end{array}$ & O. lurida & 125 & $6-44$ & $6-32$ & $2-13$ & $1.39(0.03)$ & $3.84(0.01)$ \\
\hline $\begin{array}{l}\text { Low } \\
\text { intertidal }\end{array}$ & C. gigas & 208 & $9-227$ & $7-124$ & $2-68$ & $1.60(0.03)$ & $3.55(0.01)$ \\
\hline $\begin{array}{l}\text { Low } \\
\text { intertidal }\end{array}$ & 0. lurida & 385 & $8-80$ & $6-41$ & $2-25$ & $1.46(0.02)$ & $3.82(0.01)$ \\
\hline
\end{tabular}




\section{APPENDIX 2. LENGTH-WEIGHT RELATIONSHIPS}

Linear regressions of length and dry weight relationships at each tidal height.
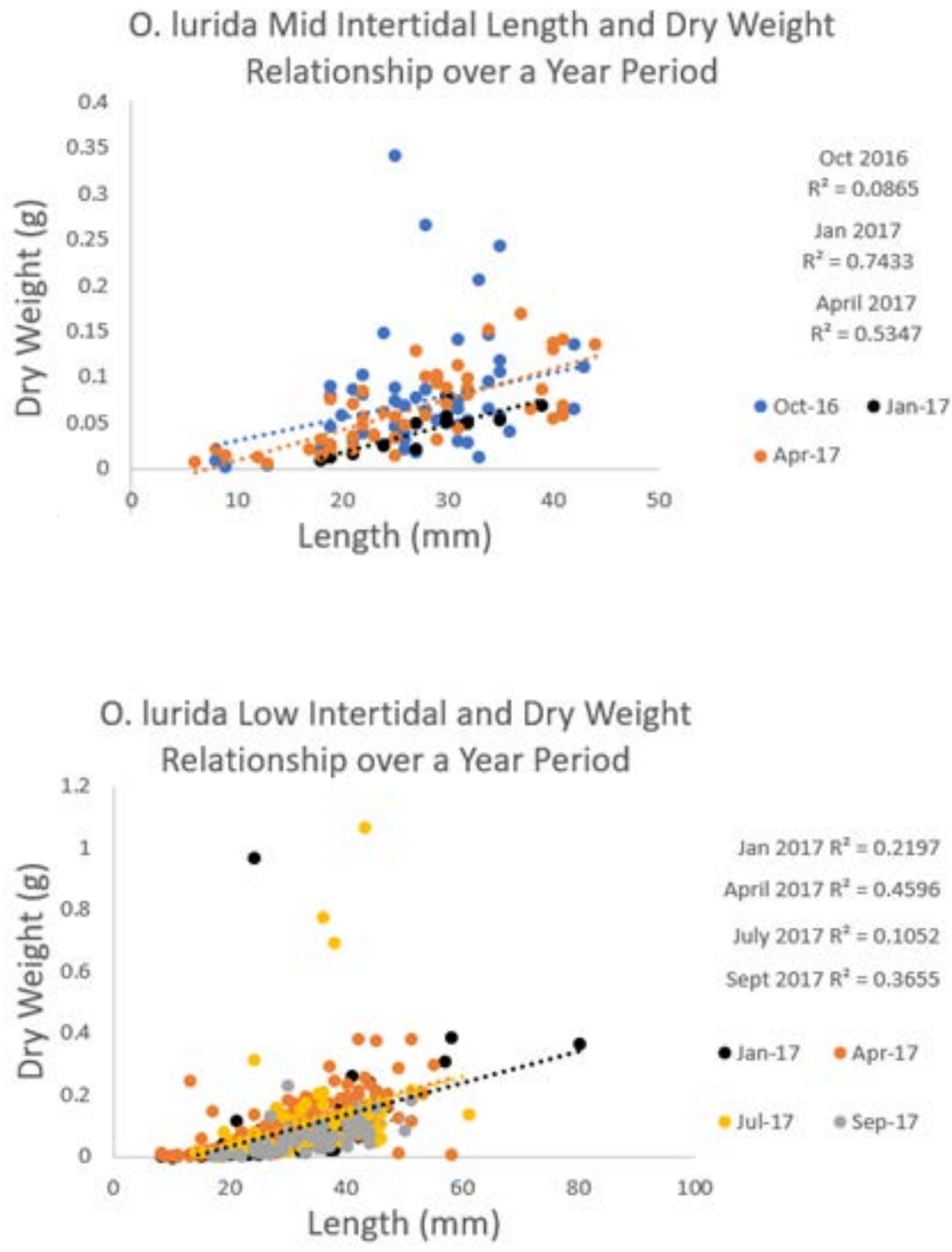
C. gigas High Intertidal Length and Dry Weight

Relationship over a Year Period

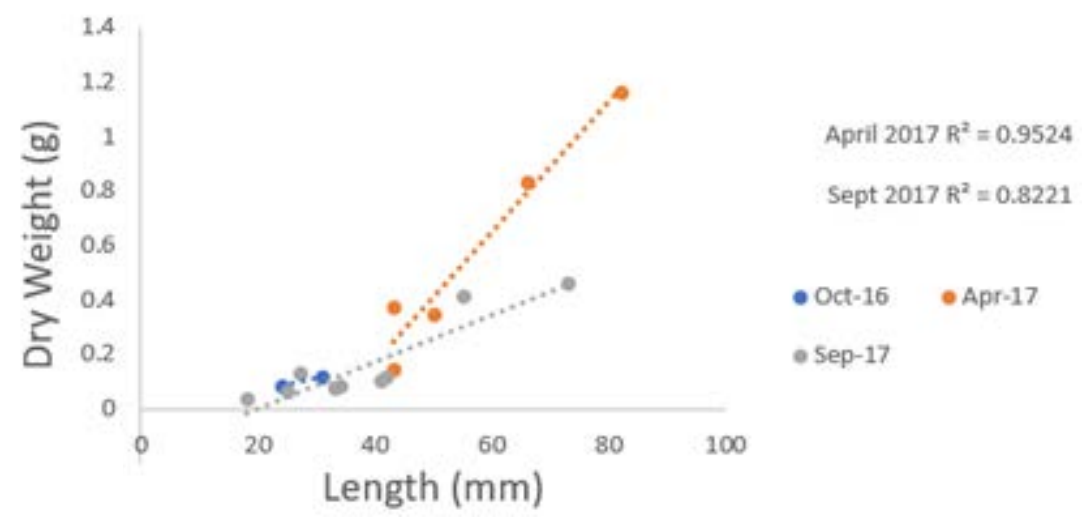

\section{C. gigas Mid Intertidal Length and Dry Weight}

Relationship over a Year Period

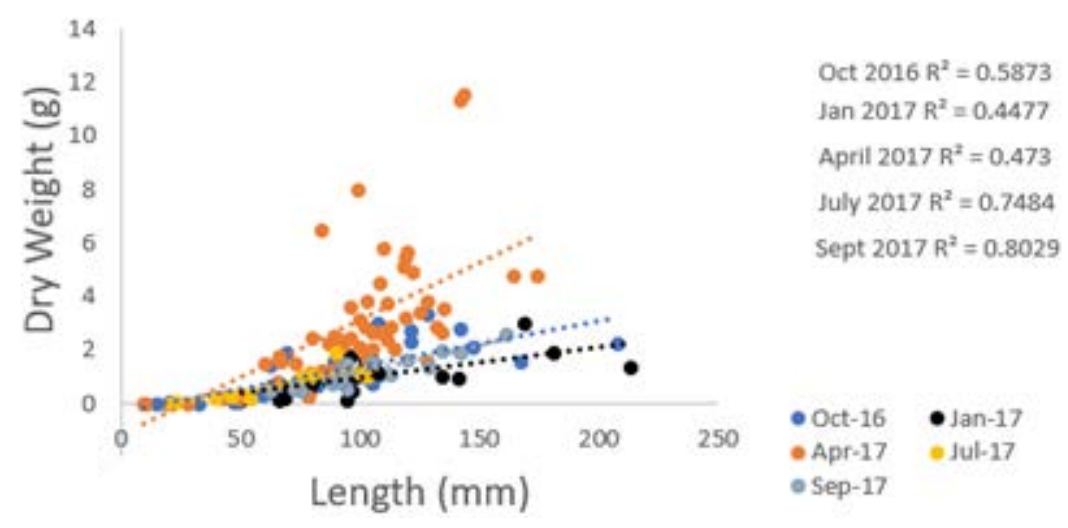

\section{C. gigas Low Intertidal Length and Dry Weight}

Relationship over a Year Period

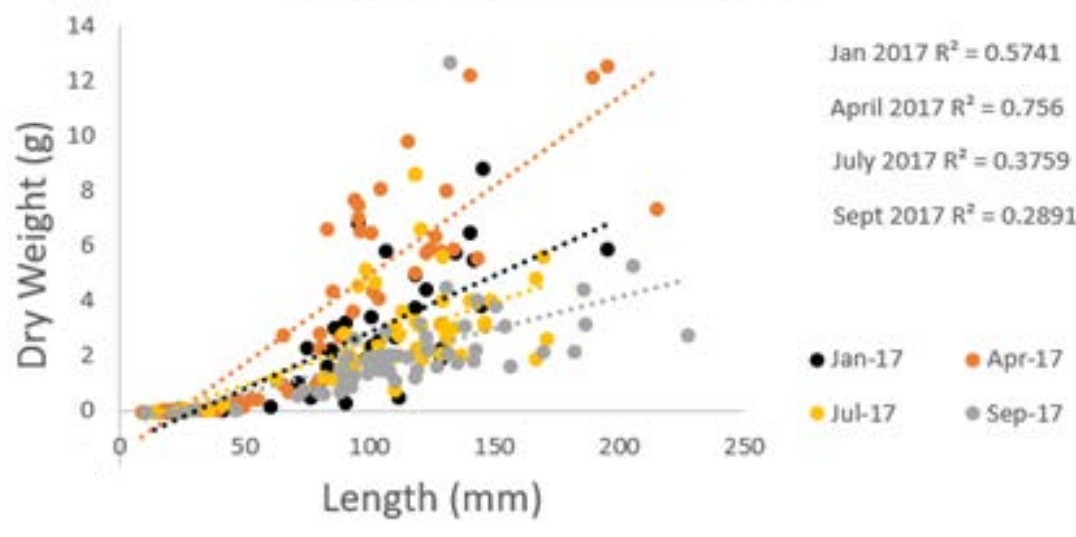

